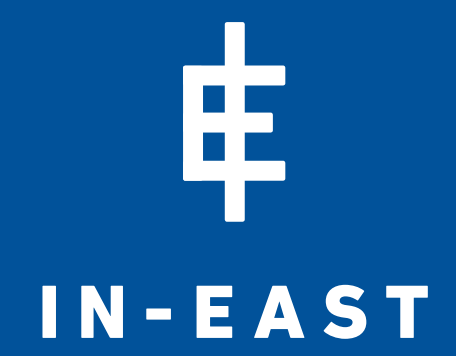

INSTITUTE OF EAST ASIAN STUDIES

TORSTEN HEINRICH S HUANPING DAI

Diversity of Firm Sizes, Complexity, and Industry Structure in the Chinese Economy

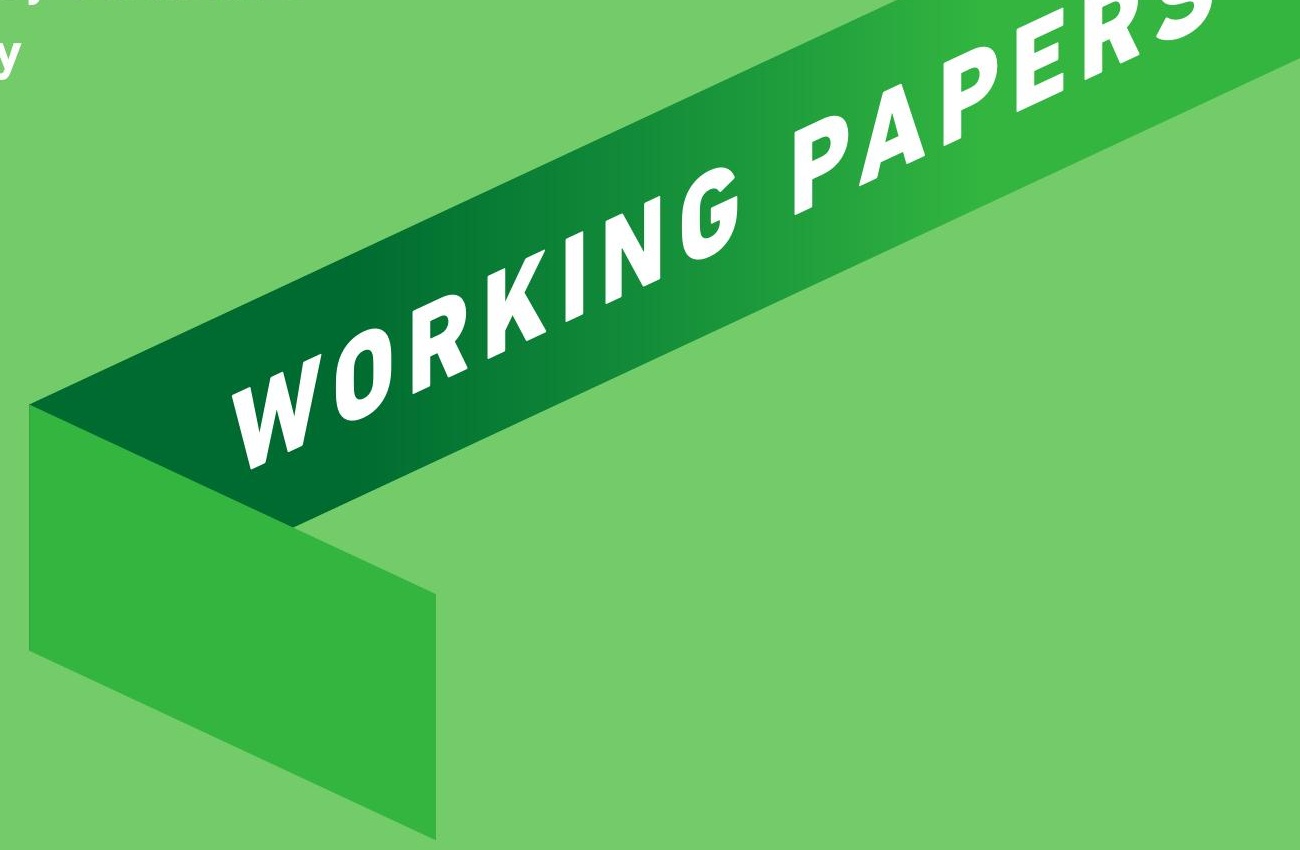

WORKING PAPERS

ON EAST ASIAN STUDIES

DECEMBER 2015 


\section{TORSTEN HEINRICH}

Research Associate, Institute for Institutional and Innovation Economics (IINO), University of Bremen W http://elsner.iino.uni-bremen.de/en/staff

E torsten.heinrich@uni-bremen.de

\section{SHUANPING DAI}

Junior Professor of Economics at the IN-EAST School of Advanced Studies and the Mercator School of Management, University of Duisburg-Essen.

W www.in-east.de

E shuanping.dai@uni-due.de

\section{Institute of East Asian Studies / Institut für Ostasienwissenschaften}

University of Duisburg-Essen

Duisburg Campus, Forsthausweg

47057 Duisburg, Germany

T +49(0) $203379-4191$

F +49(0) $203379-4157$

Ein-east@uni-due.de

ISSN: 1865-8571 (Printed version) / 1865-858X (Internet version)

Download: www.in-east.de

(c) by the authors, December 2015 


\section{CONTENT}

1 Introduction 5

2 Literature Review 6

3 Recent Economic Policy and Development in the PRC 9

3.1 China's Opening to the Market Economy 9

3.2 State-Owned Enterprise Reform 10

3.3 Township and Village Enterprises 10

4 Empirical Analysis 11

4.1 Data and Method 11

4.2 Results 11

5 Discussion of Results 17

6 Conclusion 21

References 22

$\begin{array}{ll}\text { Appendix } & 24\end{array}$ 
TORSTEN HEINRICH / SHUANPING DAI

\title{
Diversity of Firm Sizes, Complexity, and Industry Structure in the Chinese Economy
}

WORKING PAPERS ON EAST ASIAN STUDIES, NO. 107, DUISBURG 2015

\begin{abstract}
Among the phenomena in economics that are not yet well-understood is the fat-tailed (power-law) distribution of firm sizes in the world's economies. Different mechanisms suggested in the literature to explain this distribution of firm sizes are discussed in the present paper. The paper uses the China Industrial Enterprises Database to study the distribution (firm size in terms of the number of employees, capital, and gross profit) for the provinces of China for the years 1998-2008. We estimate the power-law distribution and confirm its plausibility using the KS test and the log-likelihood ratio vs. lognormal and exponential distributions. The analysis on regional levels allows an assessment of regional effects on differences in the distribution; we discuss possible explanations for the observed patterns in the light of the recent regional economic development in the PRC.
\end{abstract}

\section{Keywords}

Firm size distribution, evolutionary industry dynamics, power-law distribution, China 


\section{INTRODUCTION}

The distribution of firm sizes in the world's economies seems to be remarkably homogeneous and stable across different countries as well as across time. It has been characterized as fat-tailed, specifically as following a power law in the tail by different studies for different regions (e.g. the US (Axtell 2001), the G7 countries (Gaffeo et al. 2003), or China (Zhang et al. 2009)). Other studies (Marsili 2005; Bottazzi et al. 2007; Dinlersoz and MacDonald 2009) found that the distribution only holds on an aggregate level across either sectors or firms of different ages - which may imply an evolutionary process or a self-organized criticality system depending on typical life-cycle developments of firms. ${ }^{1}$ A consensus has not yet emerged and no generally accepted theory of how the distribution emerges has been found. There are, however, a number of candidate explanations as will be detailed in Section 2 below - an ongoing debate to which the present study will contribute as well. While differences in the shape and parameters of the distribution have been investigated for sectors (Marsili 2005; Bottazzi and Secchi 2006; Bottazzi et al. 2007) and international comparisons exist as well (Okuyama et al. 1999; Gaffeo et al. 2003) there are to our knowledge no studies of regional differences within a country. While international differences also reflect differences in political systems and culture, regional variation may highlight what actually governs the emergence of the power-law distribution and its particular shape. Of course this is also true for sectoral disaggregation, which has, however, already been studied extensively (Marsili 2005; Bottazzi et al. 2007; Bottazzi and Secchi 2006; Dosi 2007; Dosi et al. 2015). This is related to the question of the very existence and persistence of diversity in economic firms and firm sizes (moreover in exactly this pattern), a question that also seems

1 This idea was earlier proposed by Dosi et al. (1995). to require explanations related to evolutionary economics and self-organization (Nelson and Winter 1982; Dosi et al. 1995; Kwaśnicki 1998; Bottazzi and Secchi 2006).

We use the People's Republic of China's China Industrial Enterprises Database to analyze this distribution (the firm size in terms of 1 ) the number of employees, 2) capital, and 3) gross profit) for China for the years 1998 through 2008 both for the country as a whole and for individual provinces in Section 4. It is attempted to model the distribution as a power law - a hypothesis that is supported by the Kolmogorov-Smirnov test for measure 1 (number of employees), as well as for some regions for measures 2 and 3 - following the well-established methods laid out in, e.g. Clauset et al. (2009) or Maschberger and Kroupa (2009). The analysis on regional (i.e. province level) and sectoral levels allows us to assess differences in the distribution and their relation to the respective industry dynamics and regional specifics.

As firm size distributions are likely affected by - besides other factors - economic policy and development, we devote Section 3 to this aspect. The section covers the historical development of the People's Republic of China, its economic policy since the 1980s, and how this may have impacted the distribution of the firm size differently across different provinces and in comparison to other countries. Specifically, reforms and economic opening towards a market economy in the 1980s and 1990s led to a very different development of different regions regarding their distinctive industrial profile, geographic advantages, and cultural properties. It may also have provided incentive for some regions to obtain and utilize first mover advantages and to create growth opportunities for other regions. A number of coastal cities and provinces were selected as the first special economic zones to be opened to the global market in 1980s, whereas 
the Western and Central areas did not benefit directly from the reforms until the late 1990s. This makes the regional firm size distribution in China a historically unique example the study of which may help in understanding the processes behind the astounding properties and similarities of firm size distributions in economies around the world.
Section 2 discusses the literature on firm size distribution with particular emphasis on the possible origins of the power-law shape. This is followed by considerations on recent economic history in China in Section 3. Section 4 proceeds with the empirical analysis and results for which potential explanations are introduced in Section 5 . Section 6 concludes.

\section{LITERATURE REVIEW}

It had first been hypothesized by Zipf and shortly afterwards empirically substantiated by Mandelbrot and Simon ${ }^{2}$ that firm sizes follow power-law distributions, that is sizes s occur with frequency

$$
p(s)=C s^{-\alpha} \quad P\left(s>s^{*}\right)=\frac{C}{\alpha-1} s^{-\alpha+1} .
$$

In fact, it was conjectured with reasonable empirical evidence, that they specifically follow the Zipf distribution with exponent $\alpha=2$.

A number of theories have been put forward, why this might be the case (both, that the measure is power-law distributed, if the second conjecture is accepted that the exponent is $\alpha=2$ ). Notable theories include:

1 A Gibrat process, a scale-invariant growth process which converges (fast enough) to a steady-state distribution, will yield a power law with exponent $\alpha=2$. Further, processes with almost any growth rate distribution will lead to a distribution converging to a power law as long as there is a lower bound to the distribution (Kesten process) (Gabaix 1999; Axtell 2001; Delli Gatti et al. 2005; Luttmer 2007); see also item 4.

2 For a short historical overview, see Buendía (2013); for a comprehensive early theoretical account, see ljiri and Simon (1977)
2 Exponentially mixed Gaussians, that is, lognormal distributions mixed with exponentials lead to power laws under certain conditions. The lognormal distribution can for instance be given by a normally distributed growth rate, the exponential distribution can be assumed for other measures, such as the firm age (Coad 2010) or the firm's product diversity (Buldyrev et al. 2007).

3 Aggregation over not power-law distributed sectoral firm sizes as suggested by Dosi et al. (1995); Dosi (2007). The Bose-Einstein statistic, first suggested by ljiri and Simon (1977), has been proposed as the distribution of growth opportunities that are subject to increasing returns following a generalized Eggenberger-Pólya urn process and that result in Subbotin-distributed (ideally, for the infinite limit Laplace distributed) firm growth rates (Bottazzi and Secchi 2006). ${ }^{3}$

3 It should be noted that exponential (in this theory Laplacian) growth rates should sum up to sizes that are Gamma distributed, not power law. There is limited evidence for sectoral size distributions that do not match the power-law shape (Marsili 2005; Bottazzi et al. 2007). In spite of overwhelming evidence for power-law figures in the aggregated distributions, it has further been noted that scale-free power-law distributions should be persistent under disaggregation (Dosi et al. 2015) which may cast doubt on whether the true distribution indeed follows a power law. 
4 Multiplicative stochastic processes can give rise to power laws, the simplest such case being an AK model with $A$ being drawn from a uniform distribution with nonzero mean (e.g. Zhang et al. 2009).

5 The power-law property is introduced through another variable and retained in the firm size. The variable often suspected to potentially act in this way is the productivity distribution across firms. A revenue function which is exponential in the productivity with a positive exponent with an absolute value smaller than the productivity distribution's power-law exponent will then yield another power law for the revenue distribution (Helpman et al. 2004).

6 Preferential attachment in networks yields degree distributions that follow power laws. If the economy is modeled as a network where the firm size depends on the degree of the node (firm) and has a positive influence on further increase of that degree, the power law is retained in the firm size distribution (Stephen and Toubia 2009; Dahui et al. 2006).

7 Other processes involving self-organized criticality (in a similar way to Gibrat and Kesten processes) could as well be used to model the emergence of power laws (Delli Gatti et al. 2005; Battiston et al. 2007).

More recently, some scholars doubt the nature of the firm size distribution as a power law. Since its emergence is not well-understood, it is possible that the firm size actually follows an unidentified distribution similar to but different from a power law. As long as good fits can be obtained for a power law over several orders of magnitude, however, the interpretation of the parameters would remain largely unchanged; the assessment of some properties of the theoretical distribution (likelihood of 'black swans', extreme tail observations, existence of moments, convergence with increasing sample size) may change.
Empirical power-law fits of the firm size distribution generally yield power-law exponents around $\alpha=2$; the specific values reported in the literature are summarized in Table 1. There is evidence for some variation across sectors, countries, and time. However, very few scholars interpret these variations as actually meaningful. Notably, Gaffeo et al. (2003) have proposed and provided evidence for falling exponents during recessions. The literature tradition following Helpman et al. (2004) has attempted to establish that exponents firms differ between samples of exporting and non-exporting firms (di Giovanni et al. 2011; Sun and Zhang 2012).

Further, there are indications that different measures of firm sizes yield slightly different exponents (see Table 1). The exponent for sales is reported to be slightly lower than that for capital by Gaffeo et al. (2003) (but for some cases slightly higher in Fujimoto et al. (2011)). The exponent for the distribution in the number of employees is for many countries (including China) reported to be higher than that for either sales or capital in Fujimoto et al. (2011). ${ }^{4}$

While the firm size distribution is generally stable across time and geographic region, some differences have been reported; of interest for the present study are those that directly concern China. Both Duschl and Peng (2015) and Yu et al. (2015) recently found that the characteristics of Chinese firms vary greatly with the ownership structure. Duschl and Peng (2015) report lower average growth for state-owned enterprises but a much higher probability to become high growth firms while foreign owned enterprises are also more likely to show high growth rates. Yu et al. (2015) indicate larger shifts in the productivity distribution in the 1990s and 2000s resulting from exit and changes in ownership and organizational structure. Other aspects seem

4 For disaggregated (sectoral) data Bottazzi et al. (2007) even report some cases of different modality for different firm size measures. 
Table 1: Power law exponent estimates for firm size from the literature

\begin{tabular}{|l|c|c|l|l|}
\hline Author(s) & Com. CDF Exponent & PDF Exponent & Measure & Data \\
\hline Okuyama et al. (1999) & $0.72-1.40$ & $1.72-2.40$ & Income & USA, Japan 1990s \\
\hline Axtell (2001) & $0.994-1.0039$ & $1.994-2.0039$ & Employees & USA 1988-1997 \\
\hline Gaffeo et al. (2003) & $0.81-0.97$ & $1.81-1.97$ & Sales & CAN, USA, JAP, \\
\hline & $1.04-1.328$ & $2.04-2.328$ & Capital & ITA, FRA, GER, UK \\
\hline Silverberg and & $0.73-0.84$ & $1.73-1.84$ & Debt & \\
\hline Verspagen (2007) & 1.0 & 2.0 & $\begin{array}{l}\text { Innovation } \\
\text { (patent) }\end{array}$ & USA, Europe \\
\hline Helpman et al. (2004) & $0.4-1.8$ & & revenue & \\
\hline Zhang et al. (2009) & $0.937-1.013$ & $1.937-2.013$ & Revenues & Top 500 firms, China 2002- \\
\hline di Giovanni et al. (2011) & $0.949-1.111$ & $1.949-2.111$ & Employees & France \\
\hline Fujimoto et al. (2011) & $0.6315-1.2056$ & $1.6315-2.2056$ & Capital & Worldwide \\
\hline & $0.8234-1.6516$ & $1.8234-2.6516$ & Employees & China \\
\hline Sun and Zhang (2012) & $0.411-0.810$ & $1.411-1.810$ & Sales & China by sectors 1998-2007 \\
\hline Buendía (2013) & $1.096-1.328$ & $2.096-2.328$ & Market share & Telecommunications and \\
\hline & $0.7241-1.3103$ & $1.7241-2.3103$ & Sales & Aerospace sector, USA \\
\hline
\end{tabular}

unique for China as well: the variance scaling relationship (inverse linear relationship of the variance of growth rates and the logarithm of the size) differs from Western economies (the parameter being smaller) according to Duschl and Peng (2015), while Yu et al. (2015) report a very stable productivity growth distribution on the aggregated level compared to other emerging economies.

A related problem is the very existence and persistence of diversity in economic firms (moreover in exactly this pattern). Among the approaches put forward in relation to this question those from evolutionary economics (Nelson and Winter 1982; Dosi et al. 1995; Kwaśnicki 1998; Bottazzi and Secchi 2006; Dinlersoz and MacDonald 2009), for a comprehensive overview, see e.g. Kwaśnicki (1998), more recent advances which are discussed in, e.g. Schwardt and Schwesinger (2013), Dosi et al. (2015) seem to be the most promising. Several explanations have been put forward; most ob- viously, firms compete with different degree of success especially with respect to processes that are subject to uncertainty such as innovation and research.

In fact, this is the core of the earliest Schumpeterian agent-based models of economic change (Nelson and Winter 1982). More recent approaches emphasize that there may be a general mechanism that breaks the symmetry of the underlying growth and contraction process. Increasing returns (network externalities, for instance) lead to advantages for established competitors with large user bases for their products - which is arguably particularly important in modern ICTs (Arthur 1996; Bottazzi and Secchi 2006; Heinrich 2013, 2014; Buendía 2013). An alternative approach is that in the presence of different (substitutable) input factors, firm types with different factor utilization (productivity) profiles will obtain different sustainable market shares (i.e., in the steady state) (Schwardt and Schwesinger 2013). 


\section{RECENT ECONOMIC POLICY AND DEVELOPMENT IN THE PRC}

Before we proceed with the empirical analysis and the evaluation of potential explanations in Sections 4 and 5, we discuss three aspects of the recent economic history of China: the gradual opening to market economy (which happened at different times for different regions), the reform of state-owned enterprises, and the rise and fall of (also state-owned, but more decentralized) township and village enterprises. All of these and other aspects that we will merely touch upon likely have a strong impact on the current distribution of firm sizes in China. China is unique in that its transition to the market economy occurred stepwise, thus creating considerable regional variety, particularly between coastal, Central, and Western provinces, as well as resource-based provincial economies as is the case in Inner Mongolia. The differences can most clearly be seen in Figure 16 which shows the median firm age in $2008^{5}$ low in Inner Mongolia and in the Central provinces (that had recently completed their market economy transition reforms), higher in coastal regions (that completed the transition less recently) and especially in the Western part of the country (where the transition was just under way). As the pattern is clearly visible in the age distribution of firms, an effect on the size distribution should clearly be expected.

\subsection{CHINA'S OPENING TO THE MARKET ECONOMY}

In 1979, the central government started to reduce some restrictions on international trade, and offered special priorities to Guangdong and Fujian provinces. One year later, four cities, which are Shenzhen, Zhuhai, Shantou in Guang-

5 Computed from the Chinese Industrial Enterprises Database also used in Section 4. dong, and Xiamen in Fujian, were established as special economic zones, aiming at attracting international investment and building capabilities in international trade.

Inspired by the success of the special economic zones, the government decided to add more coastal cities as coastal open cities (14 cities), namely Tianjin, Shanghai, Dalian (Liaoning province), Qinhuangdao (Hebei), Yantai (Shandong), Qingdao (Shandong), Lianyungang (Jiangsu), Nantong (Jiangsu), Ningbo (Zhejiang), Wenzhou (Zhejiang), Fuzhou (Fujian), Guangzhou (Guangdong), Zhanjiang (Guangdong), Beihai (Guangxi), in 1984. At almost the same time, the government set up the Yangtze River Delta, the Pearl River Delta, and the Minnan Delta (roughly geographically equivalent to Fujian province) as economic open zones. Together with the Bohai Bay Economic Rim set up as a special economic zone in 1988, all the economic open zones which account for $20 \%$ population of China, provided a tremendous increase in the volume of China's international trade.

In 1988, the central government decided to organize Hainan Island, which had been part of Guangdong province until then, into a separate province and declare it an economic open zone.

After 1992, the central government clearly announced that China would establish a market economy system, so such kinds of economic open zones would become very common while China would become more open to and increasingly interconnected to the global market.

Looking at the development of the township and village enterprises (TVEs) in China, most TVEs were located in or focused on the opening economic zones, and provided products and services to the export sectors. 


\subsection{STATE-OWNED ENTERPRISE REFORM}

Since 1979, the Chinese government has also implemented a series of reforms in stateowned enterprises. Within the time frame considered in the empirical study in this paper, more than $90 \%$ of the state-owned enterprises were either privatized or discontinued (many went bankrupt). This might have had significant effects on the distribution of sizes, numbers, and ages of firms. Besides that, due to the asymmetric distribution of the discontinued state-owned enterprises and the emerging private enterprises, the regional distribution of firms also may have changed between 1998 and 2008. For example, after the reform of state-owned enterprises only the Eastern (coastal) provinces developed the private economy intensively. Currently, most state-owned enterprises are active in monopoly industries considered as vital and strategic sectors in terms of national security, for example, electricity, oil, natural resource, defense, etc. Moreover, the state-owned enterprises are often comparatively large and are not included in the database we used. For example, the Fortune 500 in 2014 listed 100 Chinese firms, but 92 of 100 those firms were state-owned enterprises. Therefore, calculating size distributions of firms (in terms of capital) including these large state-owned enterprises would make the distribution even more tail-heavy.

\subsection{TOWNSHIP AND VILLAGE ENTERPRISES}

Another interesting case in China is the rise and fall of township and village enterprises. Generally, township and village enterprises are firms ran in the town or village by the local government; they contributed significantly to China's reform at the early stage. Emerging at the end of the 1970s, they grew very fast. The industrial output of township and village enterprises grew at $38.2 \%$ annually in the period from 1982 to 1988; the number of employees in those enterprises grew from 28 Million in 1978 to a peak of 135 Million in 1996. But due to the following reforms, the private economy was growing much faster after 1992, most township and village enterprises were bankrupted and only a minority was privatized. For example, alone in 1995 nearly 3 Million township and village enterprises were bankrupted. Therefore, this sort of historical breaking point might have led to significant changes in the distribution of size, number, and age of firms. Most crucially, if the power-law distribution in firm sizes is assumed to be the result of self-organization processes, the time at which this vast restructuring took place may have affected the speed with which the distribution converges to the power law, as well as, more directly, relocalization decisions of certain firms, bankruptcy and start-up-establishment rates, and thus perhaps also the dispersion of firm sizes within the distribution and the parameters of the power law as suggested in Section 5.

The reforms of state-owned enterprises and township and village enterprises may also provide an explanation why the average firms in Eastern provinces are younger than their Western and Central counterparts. In the Eastern provinces, township and village enterprises have even been developed very well and private economy is very active, hence, we can assume the birth/death rate of firms in those provinces to be higher than that of other regions. 


\section{EMPIRICAL ANALYSIS}

\subsection{DATA AND METHOD}

We use the Chinese Industrial Enterprises Database for the years between 1998 and 2008 . The database contains data on between approximately 160,000 (1998) and 410,000 (2008) firms in the People's Republic of China. ${ }^{6}$

The firm size distribution is studied using three different measures: 1) the number of employees, 2) capital (specifically paid-in capital ${ }^{7}$ ), 3) gross profit as they are included in the database. ${ }^{8}$ Further, we study the firm age distribution (which we suspect not to be power-law distributed). The distributions are evaluated by year and by province.

The power-law distribution is fitted using the well-established method laid out in detail in Clauset et al. (2009) or Maschberger and Kroupa (2009). That is, the minimum value and the exponent of the power law are fitted simulta- neously, assigning each candidate minimum value a maximum likelihood exponent and choosing the exponent that minimizes the Kolmogorov-Smirnov statistic (distance of empirical and fitted CDF, cumulative distribution function). The standard error of the exponents is the bootstrapped from samples of 500 artificial distributions with the fitted parameters. The goodness of fit of the estimates is evaluated using the KS test for plausibility and Vuong's test (log-likelihood ratio with Gaussian error <0.1) for comparisons with fits

6 Only firms with revenue $>1000$ Yuan are included, which does, however, not have an impact on the present study, as we only estimate the power-law exponents of the tail of the distribution (i.e. large firms).

7 This includes share capital as well as additional revenue from shares sold in excess of par.

8 The number of employees is given as "从业人数" (number of employees), “全部职工” (all employees) etc. for different years; capital as “实收资本” (paid-in capital), and gross profits as “利润总额” (total profit). The firm age is computed from founding year and month ("开工时间 (年)”, “开工时间(月)”) as given in the database. to alternative distribution types (lognormal and exponential).

\subsection{RESULTS}

The firm size distribution in terms of capital for the entire country is shown for 2008 (as an example) in Figures 1 (PDF, probability density function) and 2 (complementary CDF); that in terms of number of employees is shown in Figures 3 (PDF) and $4 .{ }^{9}$ The power-law form is visually plausible. Further we show the firm size distribution for all three measures (number of employees, capital, gross profits) for Shanghai as an example in Figures 5, 6, 7 and for comparison the distribution of firm ages in Figure 8 (all figures complementary CDFs for 2008). It is clear that the power law is much less plausible for the firm age ${ }^{10}$ while the shapes of the other distributions are fairly close to each other.

Not all the fits for all provinces and all years were plausible - some were rejected by either the KS test or Vuong's test (vs. lognormal or exponential). ${ }^{11}$ Plausible fits were mostly stable in time (Figure 9 shows the time development for Shanghai). The exponents for the firm size distribution in terms of the number of employees were found to be somewhat higher than that for gross profits or capital in the great majority of cases. The exponents for the firm size distributions in terms of capital and gross profits were found to be generally very close to one another (with sometimes the exponent for the gross

9 We do not show the figures for the firm size distribution in terms of gross profits; it is almost identical to that in terms of capital.

10 It turned out to be statistically plausible for Shanghai for some years, but this does not hold for any of the other provinces.

11 Most fits were significantly better than the exponential fit; comparisons with lognormal were mostly inconclusive; see Table 2 . 
Figure 1: Firm size (measured in capital) distribution (probability density function),

China, 2008

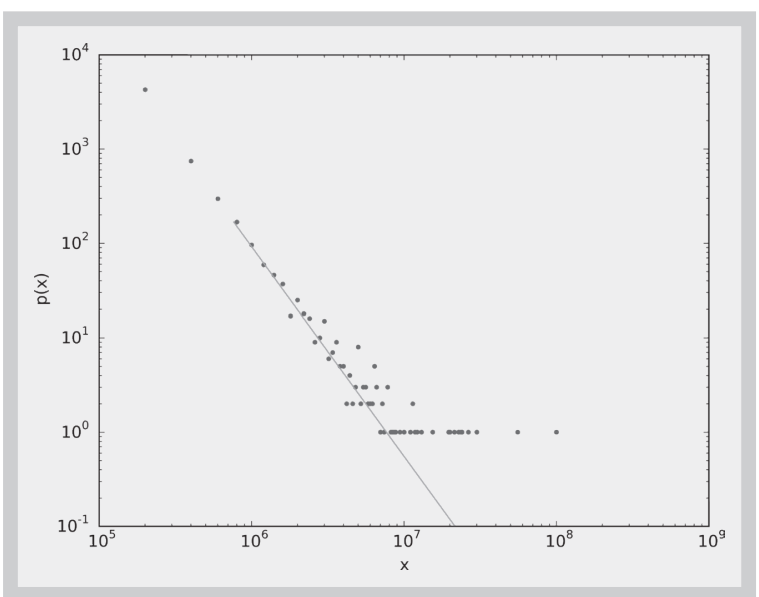

Figure 3: Firm size (measured in number of employees) distribution (probability density function),

China, 2008

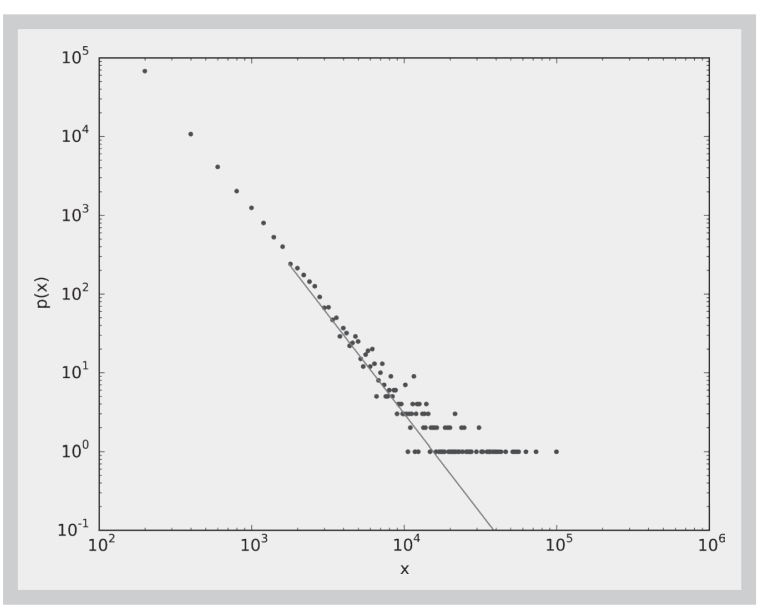

Figure 5: Survival function (complementary cumulative distribution function) for the firm size (measured in capital) distribution, Shanghai, 2008

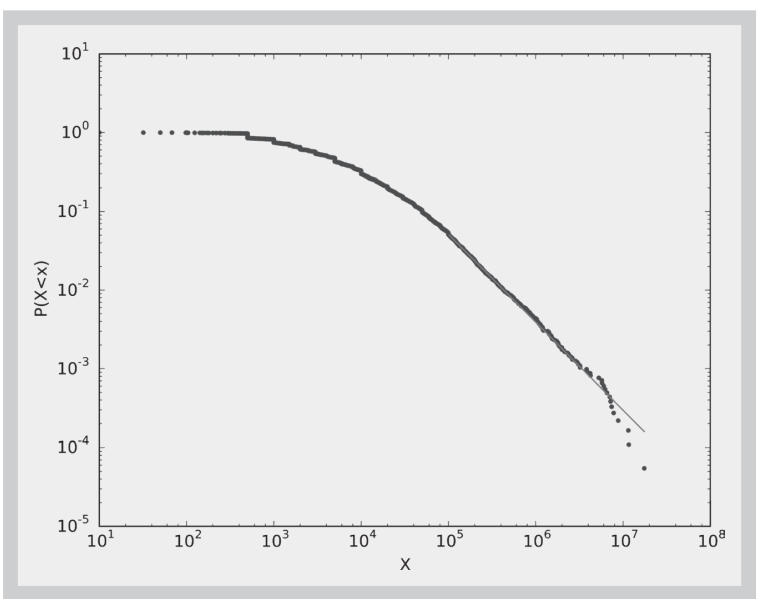

Figure 2: Survival function (complementary cumulative distribution function) for the firm size (measured in capital) distribution, China, 2008

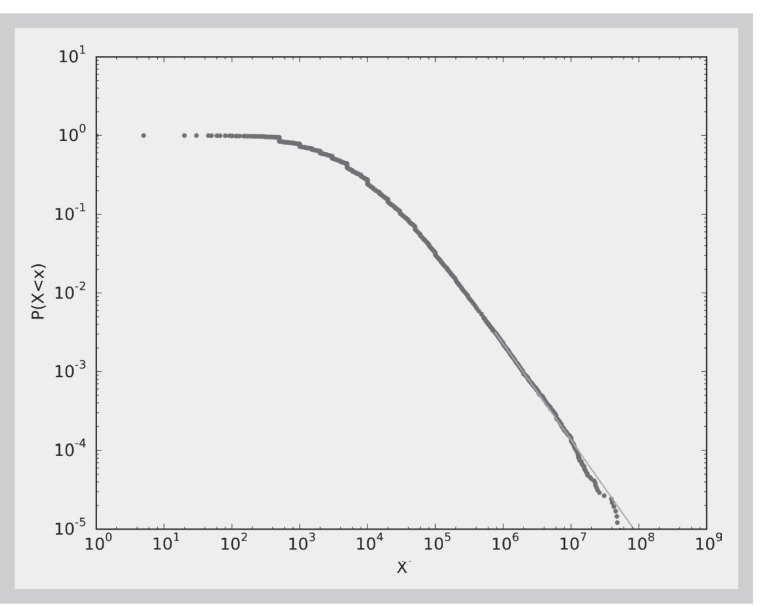

Figure 4: Survival function (complementary cumulative distribution function) for the firm size (measured in number of employees) distribution, China, 2008

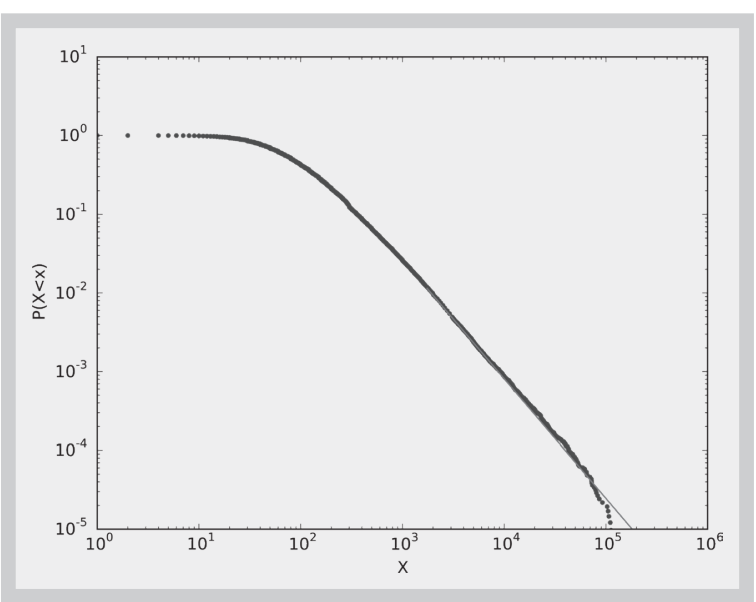

Figure 6: Survival function (complementary cumulative distribution function) for the firm size (measured in number of employees) distribution, Shanghai, 2008

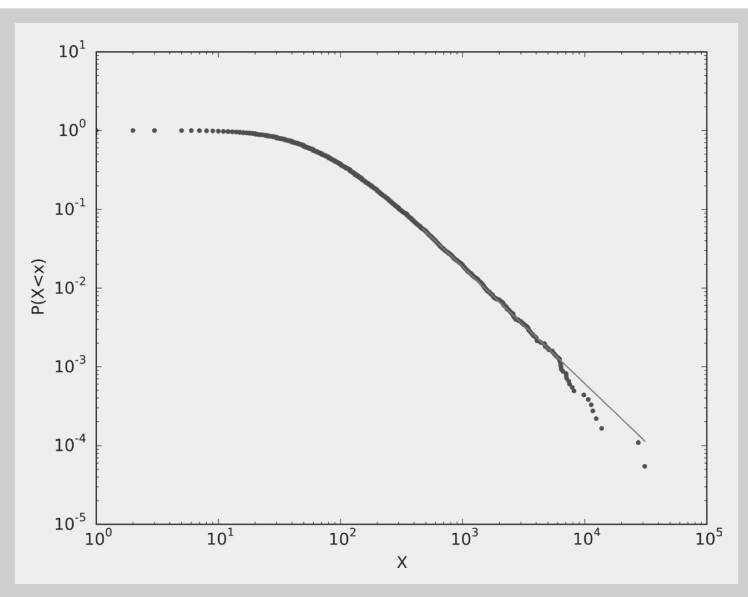


Figure 7: Survival function (complementary cumulative distribution function) for the firm size (measured in gross profits) distribution, Shanghai, 2008

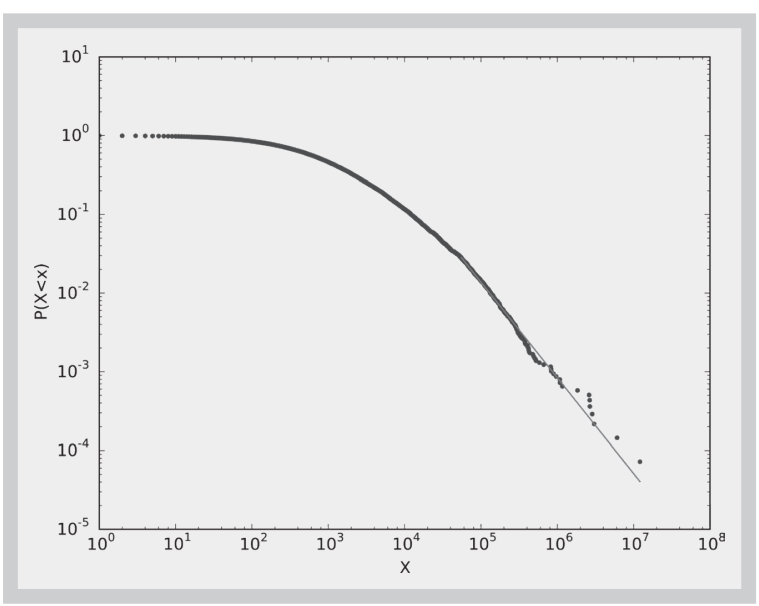

Figure 9: Development of power-law exponents for firm size in terms of capital, gross profits, and number of employees for Shanghai, 1998-2008, significant values only (KS test with $10 \%$ threshold and log-likelihood ratio vs. lognormal and exponential fit).

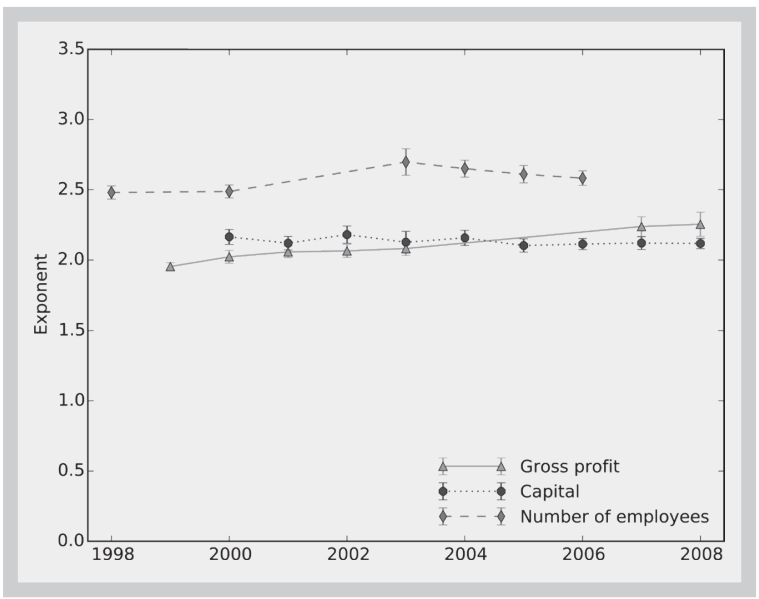

profits being slightly lower than that for capital). These empirical findings as well as the numeric estimates (some of which are given in Table 2) are in good agreement with the literature as discussed above (Zhang et al. 2009; Fujimoto et al. 2011; Gaffeo et al. 2003).

Exponents for the early (1998) and the late part (2008) of the sample are given for all provinces in Table 2 for the firm size distribution measured in number of employees and in capital. Rejected fits have, where possible, been exchanged for either better fits in the immediately succeeding
Figure 8: Survival function (complementary cumulative distribution function) for the firm age distribution, Shanghai, 2008

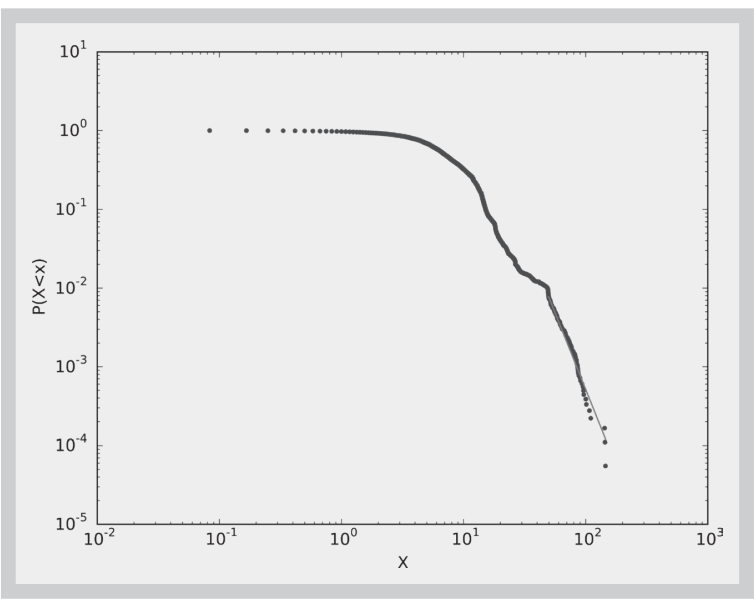

or preceding years (1999 or 2000 for 1998 and 2006 or 2007 for 2008); where this was not feasible, we have attempted to replace rejected fits for capital by fits for gross profits (since the exponents for these measures were almost always very close). There are a few instances where even so, we could not give any plausible fits or approximations from succeeding/preceding years (missing values in the table). ${ }^{12}$

We study the correlations of the so obtained samples of exponents (for provinces) with GDP growth in 1998 and in $2008^{13}$ as well as with the average firm age in 2008. Moderately good correlations are obtained between growth 1998 and the capital exponents 1998 (0.488, p-value $<0.01)$, growth 1998 and the capital exponents 2008 (0.635, $p<0.001$ ), growth 1998 and the number of employees exponents 2008 (0.321, $p<0.1)$, as well as between growth 2008 and the capital exponents 2008 (0.31, $p<0.1$ ), and between the median firm age 2008 and the capital exponents $1998(-0.533, p<0.01)$ and 2008 $(-0.531, p<0.01)$ as well as the median firm age 2008 and the number of employees exponents

12 For Tibet (Xinjiang), the sample size was too small to obtain reasonably good estimates.

13 Data from China Statistical Yearbooks from the National Bureau of Statistics in China, http://www.stats.gov.cn. 
$1998(-0.345, p<0.1)$ and $2008(-0.326, p<0.1)$. The exponents are all positively correlated among themselves, $p<0.01$.

The geographic distribution is illustrated in Figures $10,11,12,13,14,15$, and 16 . That the exponents are closely related can most clearly be seen from the Eastern and Southern coastal areas between Guangdong, Shanghai, and Tianjin. From Figures 14, 15, and 16, it can also be seen that there is a connection between exponents on the one hand and both GDP growth and firm age on the other hand (as indicated in the correlation coefficients above).

Table 2: Fitted power-law exponents and KS p-value for firm size measured by capital and number of employees, by province, 1998 and 2008. Significant fits only (KS-test and log-likelihood ratio vs. lognormal and exponential fits); for some values not significant fits were replaced with significant fits of successive or previous years (1999 or 2000 instead of 1998; 2006 or 2007 instead of 2008, indicated by superscript 1); for some values not significant fits for capital were replaced for significant fits for gross profits (indicated by superscript 2); fits significantly superior to exponential fits (log-likelihood ratio) are indicated by superscript 3; fits that fail to achieve the $10 \%$ level of the KS p-value but still have a KS p-value $>2.5 \%$, thus significant with a higher error probability, are indicated by superscript 4.

\begin{tabular}{|c|c|c|c|c|c|c|c|c|}
\hline egion & (\#Emp. 1998) & $\mathrm{KS} p$ & $\alpha$ (\#Emp. 2008) & KS p & $\alpha$ (Cap. 1998) & KS $p$ & $\alpha$ (Cap. 2008) & $\mathrm{KS} p$ \\
\hline Inner Mongolia & $2.087 \pm 0.062$ & $0.326^{3}$ & $2.248 \pm 0.041$ & $0.176^{3}$ & $1.933 \pm 0.075^{12}$ & $0.304^{3}$ & $1.853 \pm 0.041^{1}$ & $0.03^{34}$ \\
\hline Shanxi & $2.149 \pm 0.038$ & $0.25^{3}$ & $2.152 \pm 0.033$ & $0.128^{3}$ & $1.903 \pm 0.027$ & $0.256^{3}$ & $2.0 \pm 0.058^{1}$ & $0.164^{3}$ \\
\hline ebei & $17 \pm 0.043$ & $0.356^{3}$ & $2.323 \pm 0.05^{1}$ & $468^{3}$ & $2.014 \pm 0.04$ & $624^{3}$ & $2.009 \pm 0.042^{1}$ & $0.192^{3}$ \\
\hline Beijing & $2.337 \pm 0.061^{1}$ & $0.2^{3}$ & $2.301 \pm 0.047$ & $0.88^{3}$ & $2.119 \pm 0.074$ & $.45^{3}$ & $2.068 \pm 0.078^{1}$ & $0.122^{3}$ \\
\hline Liaoning & $2.227 \pm 0.048^{1}$ & $0.418^{3}$ & $2.226 \pm 0.043^{1}$ & $0.462^{3}$ & $1.941 \pm 0.037^{1}$ & $0.448^{3}$ & $1.95 \pm 0.048^{1}$ & $0.474^{3}$ \\
\hline Jilin & & & $2.14 \pm 0.068$ & $0.65^{3}$ & $2.056 \pm 0.078^{1}$ & $0.148^{3}$ & $2.046 \pm 0.084^{1}$ & $0.42^{3}$ \\
\hline Heilon & & & $2.074 \pm 0.035^{1}$ & $0.492^{3}$ & $1.121 \pm 0.040$ & $0.14^{3}$ & 3 & $0.362^{3}$ \\
\hline Shanghai & $2.481 \pm 0.047$ & $0.578^{3}$ & $2.583 \pm 0.052^{1}$ & $0.234^{3}$ & $2.165 \pm 0.053^{1}$ & $0.268^{3}$ & $2.118 \pm 0.037$ & $0.642^{3}$ \\
\hline Jiangsu & $2.803 \pm 0.084^{1}$ & $0.244^{3}$ & & & $2.416 \pm 0.087^{1}$ & $0.04^{34}$ & $2.411 \pm 0$. & $0.266^{3}$ \\
\hline Anhui & $2.606 \pm 0.083$ & $0.11^{3}$ & $2.34 \mathrm{~J} \pm 0.040$ & 0.202 & $1.751 \pm 0.034$ & $0.36^{3}$ & $1.981 \pm 0.065$ & $0.22^{3}$ \\
\hline Shandon & & & $2.581 \pm 0.074$ & $0.304^{3}$ & $2.308 \pm 0.063$ & $0.164^{3}$ & $2.236 \pm 0.05$ & $0.148^{3}$ \\
\hline Tianjin & 1 & $0.256^{3}$ & $2.281 \pm 0.045^{1}$ & $0.108^{3}$ & $2.144 \pm 0.071^{1}$ & $0.14^{3}$ & $2.104 \pm 0.046$ & $0.032^{3}$ \\
\hline Zhejian & 3 & $0.366^{3}$ & $2.857 \pm 0.055$ & $0.422^{3}$ & $2.39 \pm 0.116^{1}$ & $0.388^{3}$ & $2.441 \pm 0.053^{1}$ & $0.186^{3}$ \\
\hline Jiangxi & $656+8$ & $0.306^{3}$ & $2.458 \pm 0.083^{1}$ & $0.73^{3}$ & $2.066 \pm 0.089$ & $0.634^{3}$ & $2.136 \pm 0.084^{1}$ & $0.14^{3}$ \\
\hline Fujian & & & & & $2.222 \pm 0.054$ & $0.152^{3}$ & $2.353 \pm 0.104$ & $0.426^{3}$ \\
\hline Chong & 9 & $0.808^{3}$ & $2.391 \pm 0.071^{1}$ & $0.696^{3}$ & $2.11 \pm 0.074$ & $0.18^{3}$ & 2 & $0.2^{3}$ \\
\hline Hunan & $2.584 \pm 0.112$ & $0.516^{3}$ & $2.418 \pm 0.056^{1}$ & $0.51^{3}$ & $1.947 \pm 0$. & $0.074^{34}$ & $2.145 \pm 0.08$ & $0.458^{3}$ \\
\hline Hubei & $2.55 \pm 0.09^{1}$ & $0.284^{3}$ & $2.516 \pm 0.073$ & $0.18^{3}$ & $2.169 \pm 0.081$ & $0.506^{3}$ & $2.042 \pm 0.062^{1}$ & $0.144^{3}$ \\
\hline Henan & $2.465 \pm 0.054$ & $0.17^{3}$ & $2.286 \pm 0.035^{1}$ & $0.318^{3}$ & $2.033 \pm 0.04$ & $0.376^{3}$ & $2.072 \pm 0.044$ & $0.206^{3}$ \\
\hline Guangd & $2.819 \pm 0.068$ & $0.068^{34}$ & $2.636 \pm 0.048$ & $0.044^{34}$ & $2.671 \pm 0.1^{1}$ & $0.52^{3}$ & $2.39 \pm 0.05^{1}$ & $0.114^{3}$ \\
\hline Guangxi & $2.63 \pm 0.101$ & $0.546^{3}$ & $2.725 \pm 0.143^{1}$ & $0.432^{3}$ & $2.206 \pm 0.06$ & $0.12^{3}$ & $2.187 \pm 0.09^{1}$ & $0.144^{3}$ \\
\hline Guizł & $2.482 \pm 0.164$ & $0.566^{3}$ & $2.379 \pm 0.057$ & $0.206^{3}$ & $2.134 \pm 0.104^{1}$ & $0.576^{3}$ & $1.837 \pm 0.032^{1}$ & $0.186^{3}$ \\
\hline Hainan & $3.271 \pm 0.323^{1}$ & 0.598 & $2.731 \pm 0.178^{1}$ & $0.326^{3}$ & $2.285 \pm 0.148$ & $0.246^{3}$ & $1.864 \pm 0.079^{1}$ & $0.206^{3}$ \\
\hline Sichuan & $2.586 \pm 0.108$ & $0.1^{3}$ & $2.466 \pm 0.051$ & $0.304^{3}$ & $2.36 \pm 0.089^{1}$ & $0.146^{3}$ & $2.17 \pm 0.05^{1}$ & $0.304^{3}$ \\
\hline Yunnan & $2.399 \pm 0.078$ & $0.238^{3}$ & $2.6 \pm 0.078$ & $0.416^{3}$ & $2.017 \pm 0.053$ & $0.554^{3}$ & $1.891 \pm 0.035^{1}$ & $0.038^{34}$ \\
\hline Shaanxi & $2.496 \pm 0.125$ & $0.236^{3}$ & $2.079 \pm 0.032$ & $0.708^{3}$ & $2.182 \pm 0.087^{1}$ & $0.146^{3}$ & $1.939 \pm 0.044^{1}$ & $0.244^{3}$ \\
\hline 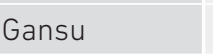 & $2.104 \pm 0.054^{1}$ & $0.536^{3}$ & $2.259 \pm 0.059$ & $0.254^{3}$ & $1.811 \pm 0.042$ & $0.214^{3}$ & $1.846 \pm 0.037$ & $0.126^{3}$ \\
\hline Igxid & $2.131 \pm 0.084$ & $0.442^{3}$ & $2.06 \pm 0.063$ & $0.292^{3}$ & $1.748 \pm 0.056^{1}$ & $0.458^{3}$ & $1.805 \pm 0.055^{1}$ & $0.588^{3}$ \\
\hline Qinghai & $2.337 \pm 0.17$ & 0.514 & $2.127 \pm 0.134$ & $0.502^{3}$ & $1.869 \pm 0.071$ & $0.412^{3}$ & $1.931 \pm 0.121$ & $0.502^{3}$ \\
\hline Xinjiang & $2.391 \pm 0.117^{1}$ & $0.226^{3}$ & $2.213 \pm 0.101$ & $0.322^{3}$ & $2.025 \pm 0.074$ & $0.25^{3}$ & $1.868 \pm 0.069$ & $0.482^{3}$ \\
\hline
\end{tabular}


Figure 10: Power-law exponents for firm size measured in capital, by province, 1998, values as in Table 2

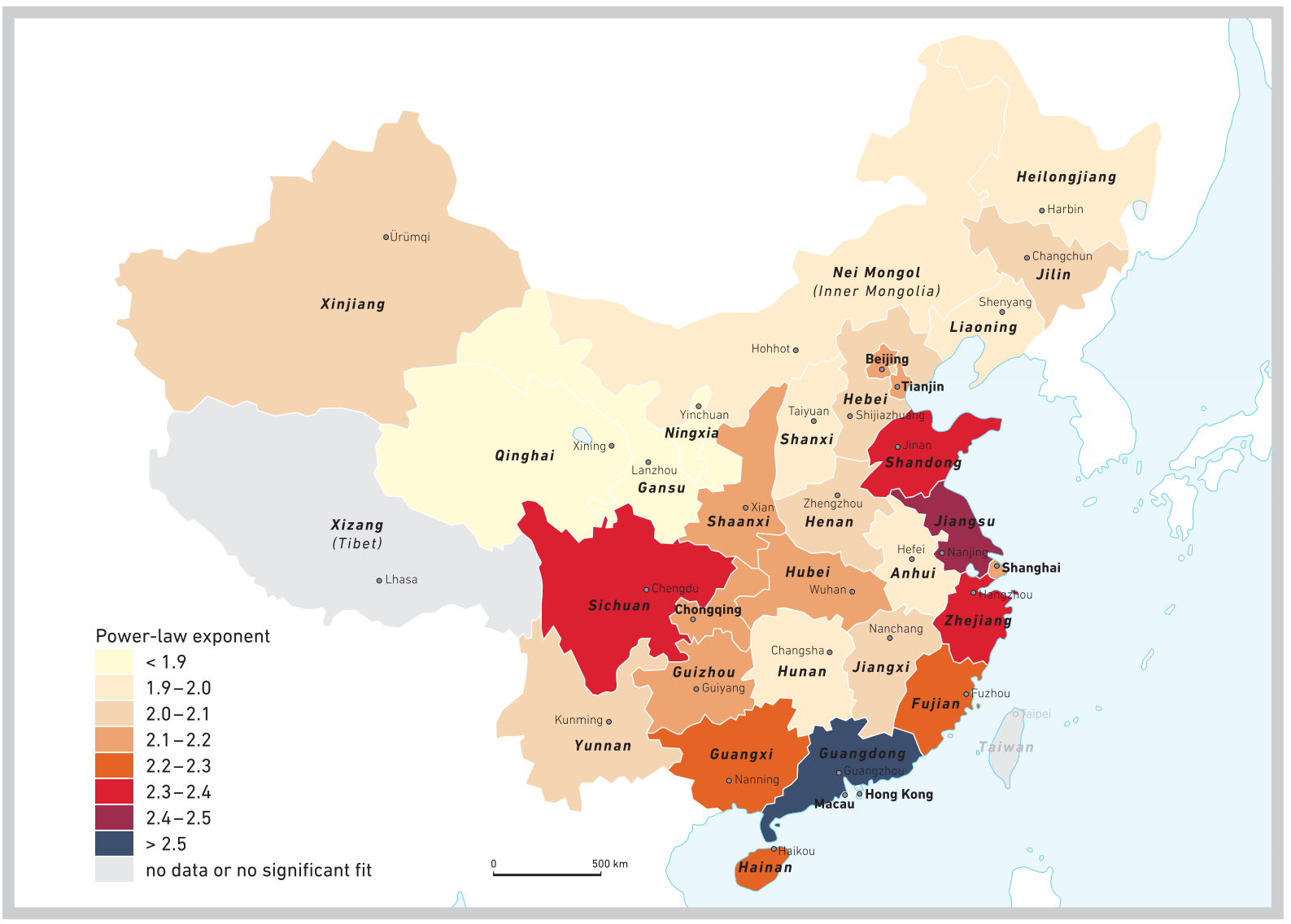

Figure 11: Power-law exponents for firm size measured in capital, by province, 2008, values as in Table 2

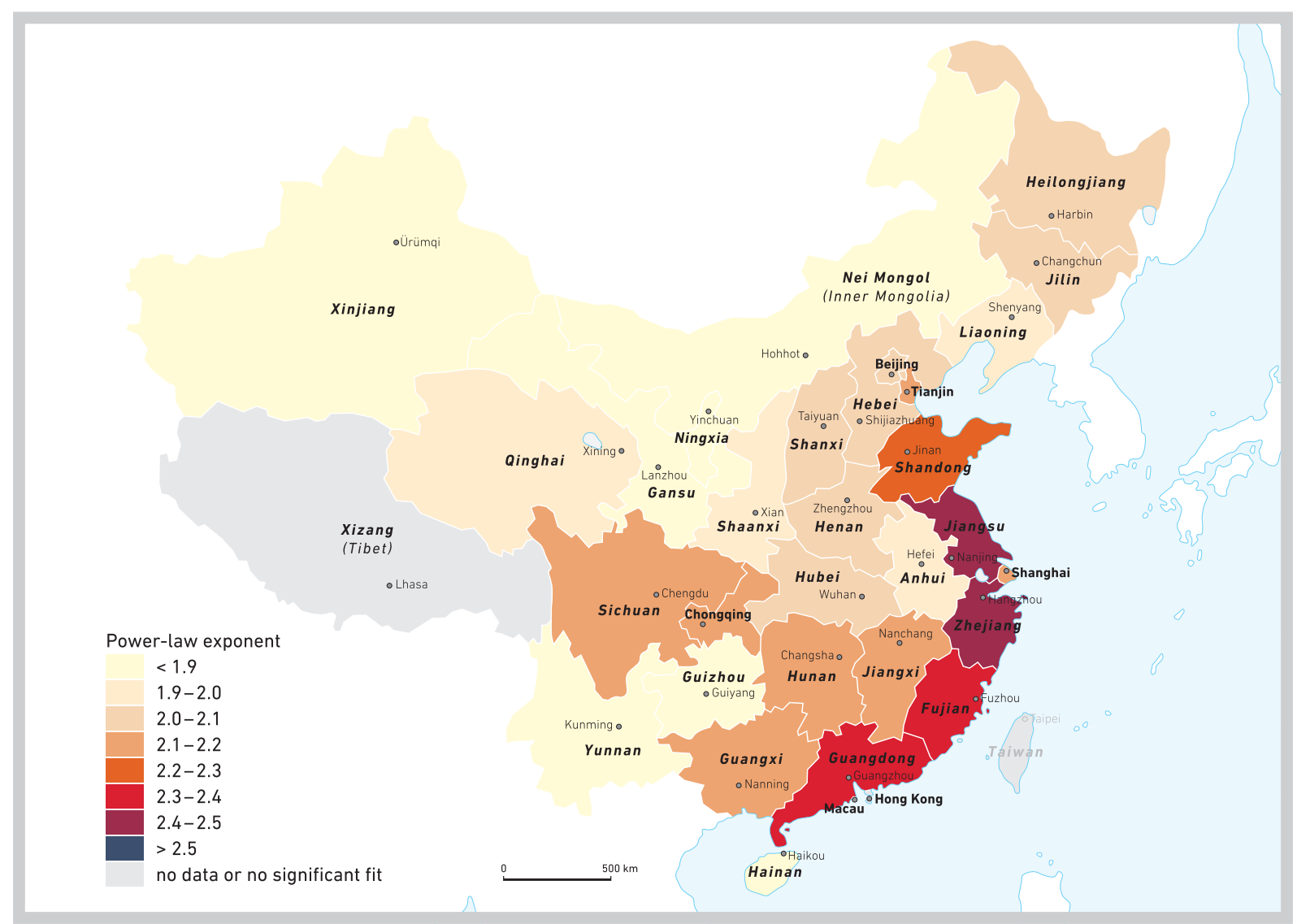


Figure 12: Power-law exponents for firm size measured in number of employees, by province, 1998, values as in Table 2

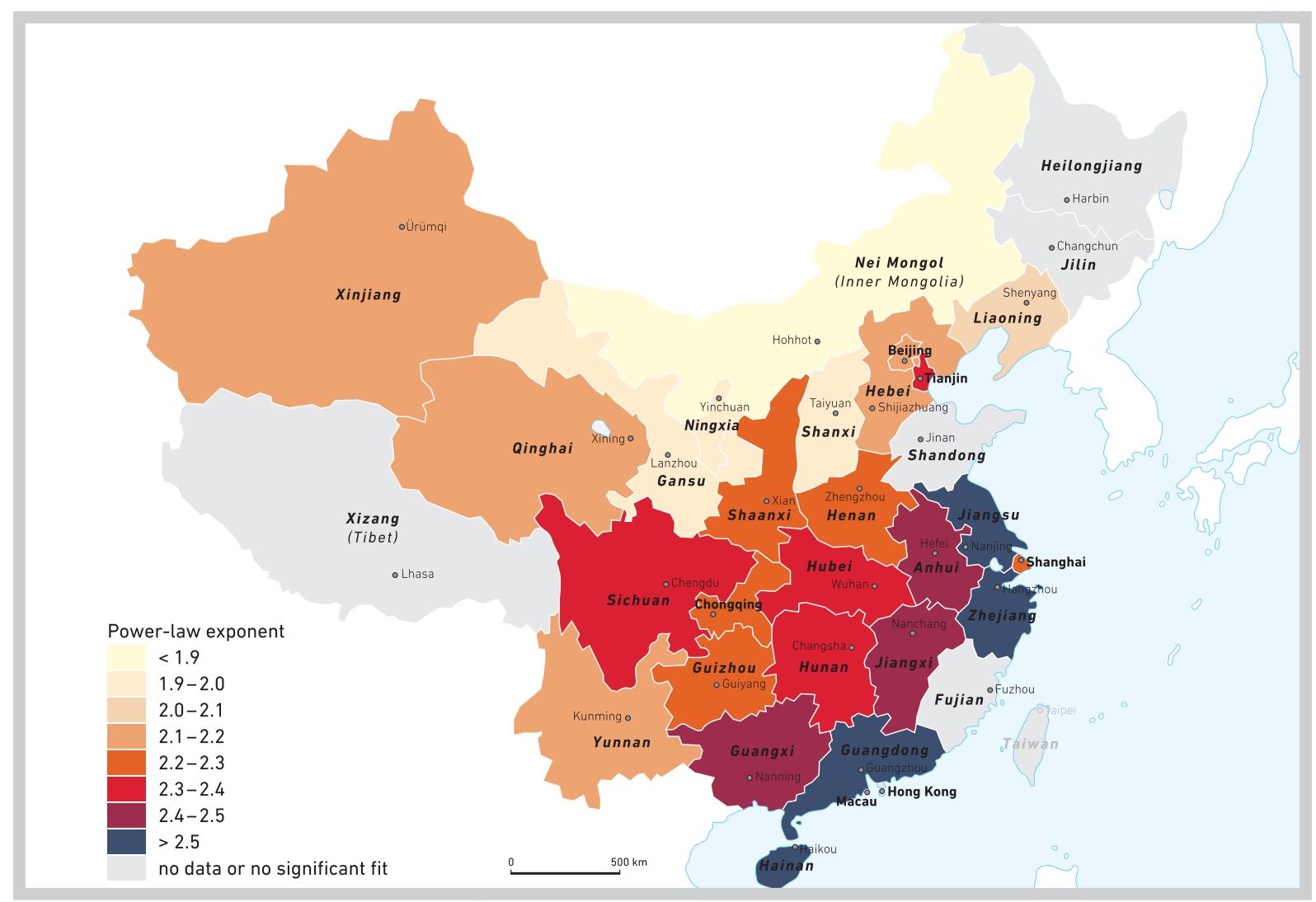

Figure 13: Power-law exponents for firm size measured in number of employees, by province, 2008, values as in Table 2

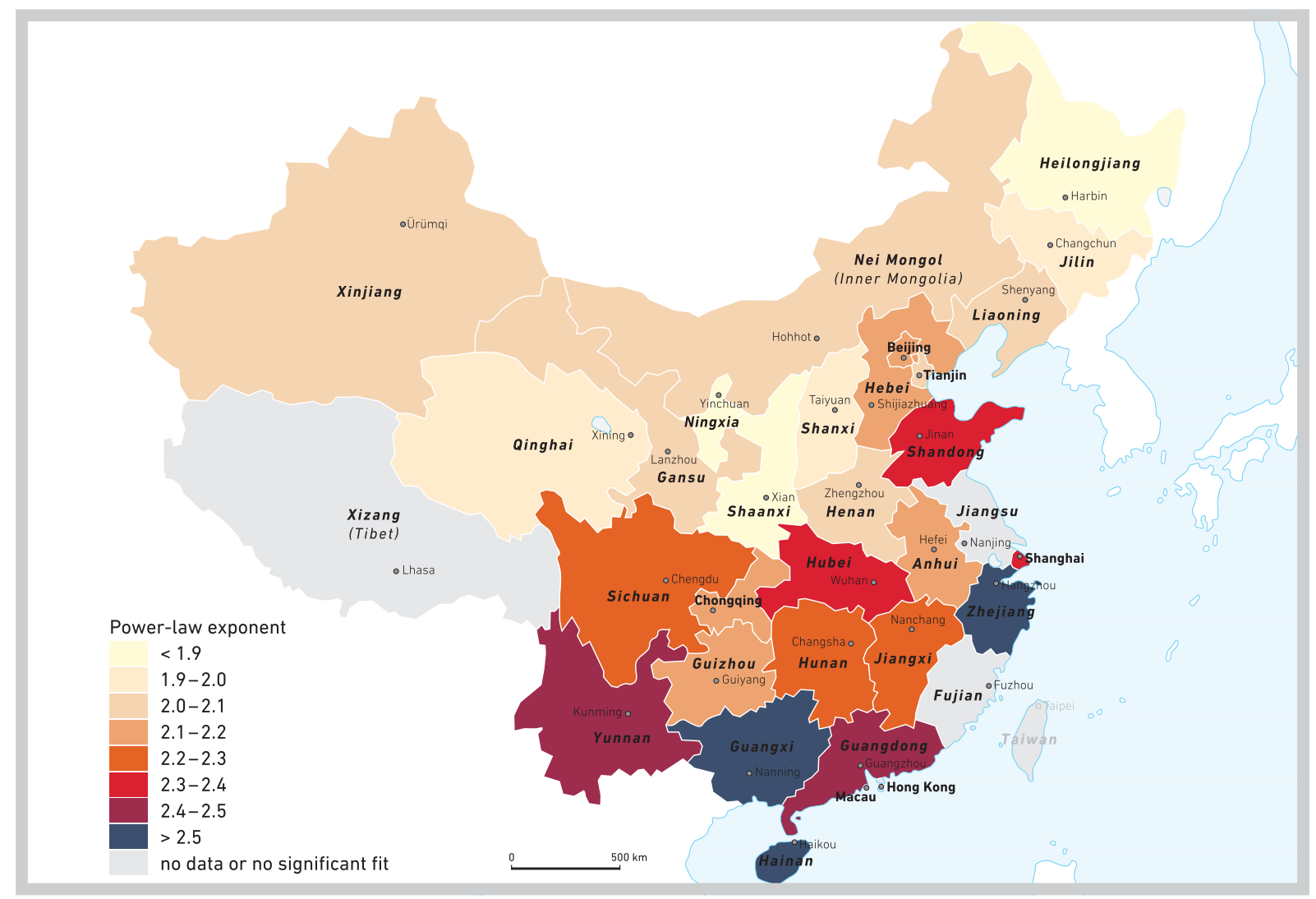




\section{DISCUSSION OF RESULTS}

In the light of the recent economic development in China as detailed in Section 3, it is likely that it also had a strong effect on the firm size distribution. As mentioned, the first regions where the transition to a more open market economy was implemented were the coastal regions, the very regions that also visibly stand out in the pattern of power-law exponents estimated in Section 4 (see Figures 10 through 13). Power-law exponents were higher in these regions, indicating 1) a steeper tail distribution with less weight on extreme tail events (super-large firms in this case), 2) a smaller dispersion, smaller skewness, etc., and, if the distribution indeed obeys a power law, 3) the finiteness of the mean of the distribution. ${ }^{14}$ This result is not intuitive as it is precisely the coastal region where some of the most dynamic industrial clusters, the financial centers, and the headquarters of some of the largest firms are located which would suggest a particularly large dispersion and high share of tail observations (i.e. small exponents). However, the rest of the distribution seems to adjust in a way that does not only counterbalance this but tilts the exponent into the other (higher) direction.

Potential consequences of different exponents include a relatively higher confidence in handling the tail of the distribution. In particular, the distribution financial risk associated with individual bankruptcies (i.e. not taking into account ownership and lending interconnections, resulting potential bankruptcy cascades and systemic risk ${ }^{15}$ )

14 The ith moment of power-law distributions with exponent $\alpha$ exists (is finite) if and only if $i \leq \alpha-1$. Consequently, the mean exists for most of the cases observed in our study (different from some findings reported in the literature, see Table 1), those with $\alpha \geq 2$, while the variance and higher moments are almost never finite. If the distribution was not a power law (we found no clear dominance between power law and lognormal fits for instance), this would be different.

15 The distribution resulting from this would be more skewed with even higher likelihood of tail events. will follow the same distribution if there is no additional connection between firm size and likelihood of bankruptcy. In this case, higher exponents will increase the predictability and, by extension, controllability of disastrous bankruptcies and probably (depending on the structure of the ownership and lending network) also that of systemic risk. ${ }^{16}$

The nature of the distribution as a power law as such indicates that the shape of the distribution is likely invariant to scaling including aggregation and disaggregation as long as these operations remain unbiased. ${ }^{17}$

However, the question of the origin of the powerlaw shape remains unanswered as does the related question for the reason for the systematic differences in exponents found across regions.

As seen in Figures 14 through 16, the Eastern coastal regions (that tend to have higher exponents) also differ markedly from Central and Western China in terms of growth rates and firm age, which suggests a possible connection, e.g. that the effect of economic development on the firm size distribution might be mediated by either growth or firm age or both.

Both of these effects are theoretically possible (as are many others) and can be modeled.

First, higher exponents may result from comparatively higher growth in the small and me-

16 This argument is particularly valid for the firm size measured in pay-in capital and perhaps gross profit (since it may indicate a higher capacity to react to liquidity problems), less so for the number of employees.

17 As mentioned above, the failure to maintain the power law under sectoral disaggregation in some studies has cast doubt on the nature of the distribution; it is, however, possible that sectoral disaggregation is not always unbiased while regional disaggregation apparently is (at least for the scales we study). 
Figure 14: Annual growth 1998 by province

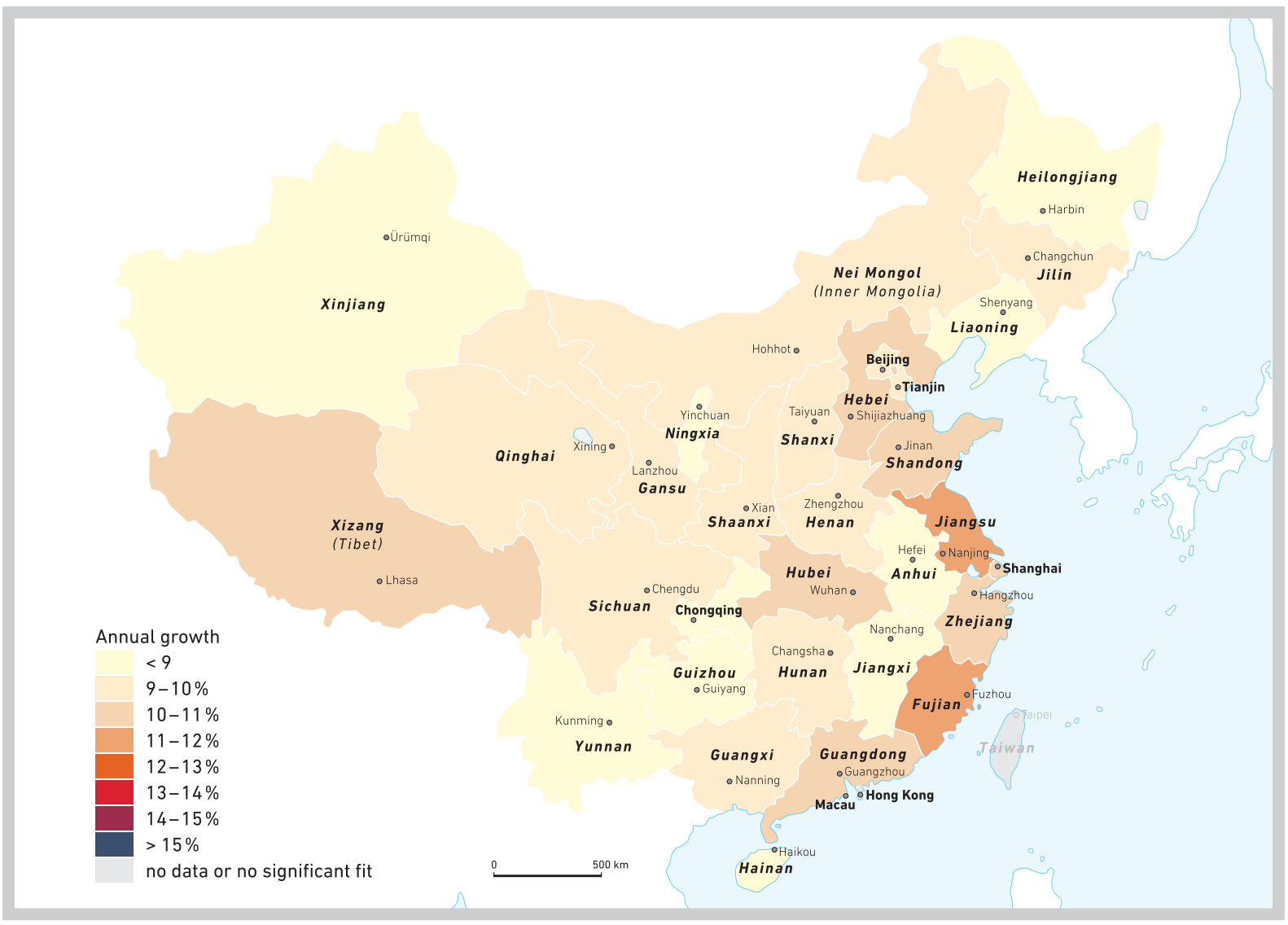

Figure 15: Annual growth 2008 by province

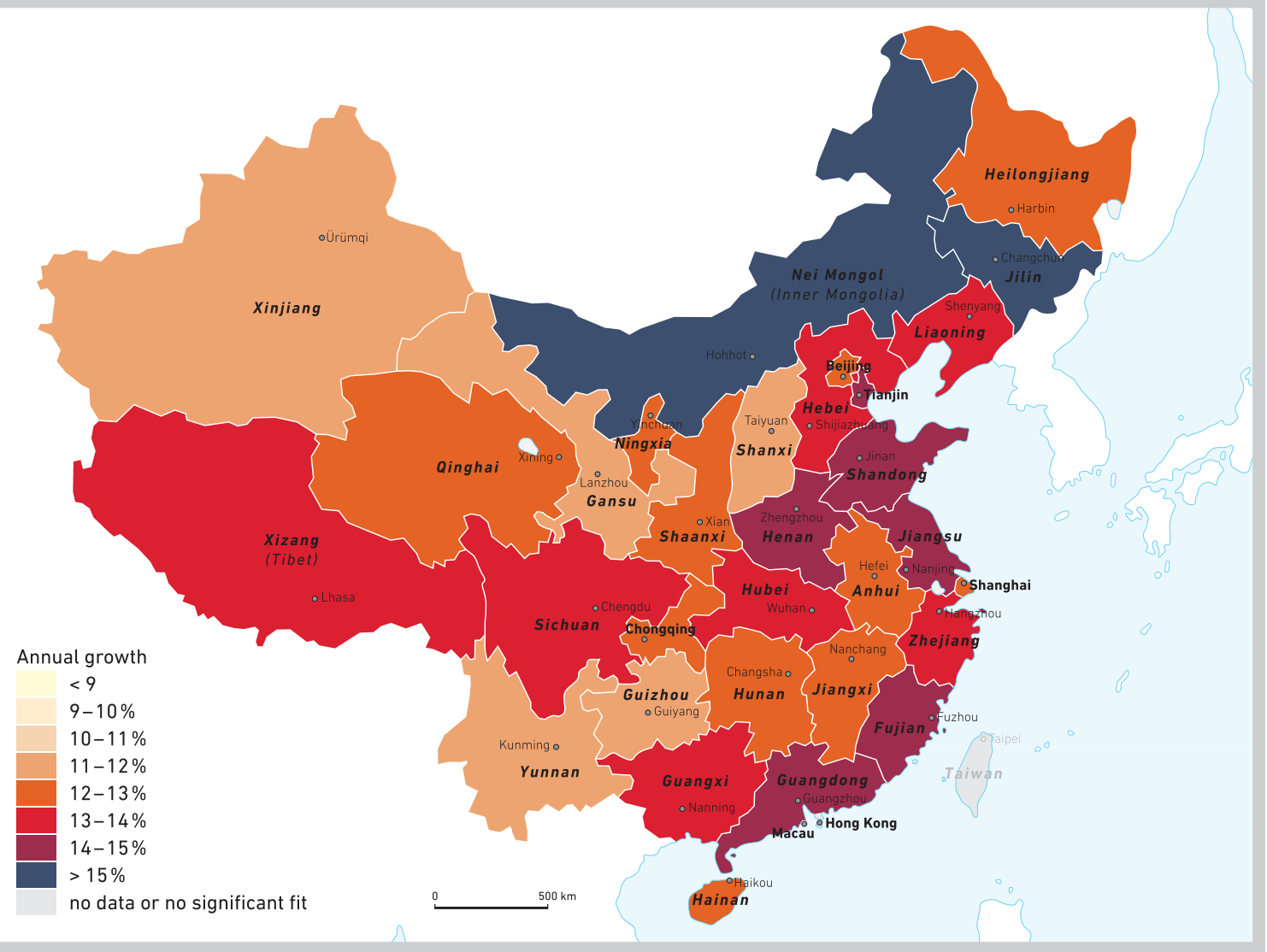




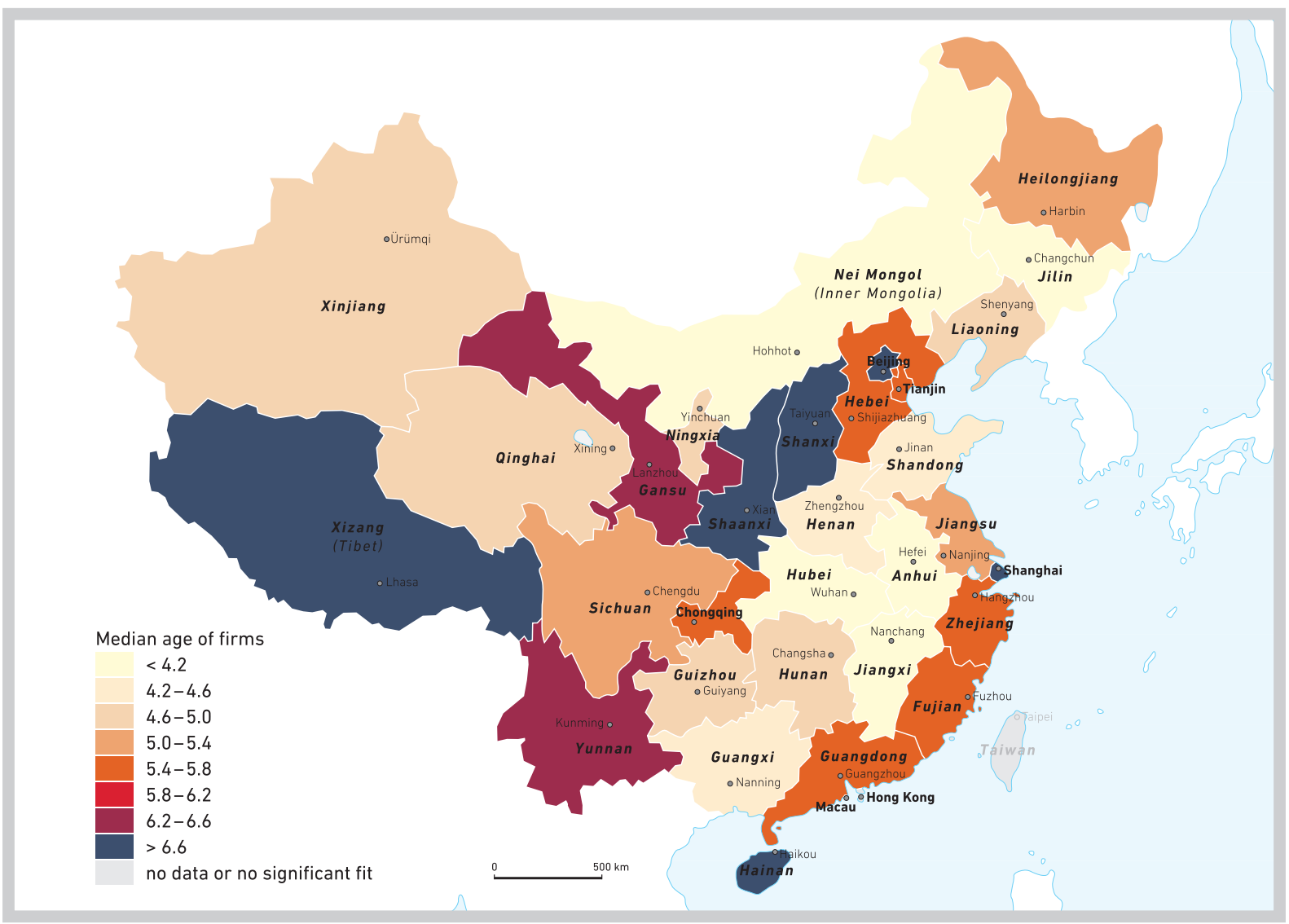

dium-sized firms (low and middle part of the distribution) while the distribution maintains the characteristic overall shape as a result of one of the mechanisms discussed in Section 2. The reason for such a process may lie in direct stimulation of growth in smaller firms, in better R\&D performance of smaller firms, in the removal of market entry barriers, or in greater ease of doing business for smaller enterprises and start-ups. Any or all of these may be associated with the transformation to the market economy. Consider as a simple computational example a growth process satisfying this setting

$$
y=g(x)=k \sqrt[h]{x}
$$

(with $h>1$ and $k$ sufficiently large that $E(y)>E(x)$ ) acting on power-law distributed firm sizes

$$
p(x)=C x^{-\alpha} .
$$

The resulting distribution is

$$
p(y)=\frac{d g^{-1}}{d y} p\left(g^{-1}\right)=C h k^{h(1-\alpha)} y^{-\alpha h-1+h}=\tilde{C} y^{-\alpha h-1+h}
$$

where $\tilde{C}=\operatorname{Chk}^{h(1-\alpha)}$ is the new constant and the new exponent is larger than the old one $\alpha h+1-h>\alpha$, see Appendix A.

Second, the reforms led to break-ups (even bankruptcies) of some of the large state-owned enterprises which may have eliminated a part of the tail of the distribution ${ }^{18}$ with smaller firms reacting to this thereby restoring the distribution's power-law shape.

Third, if the origin of the power-law distribution is indeed the Gibrat process (or the Kesten process), the distribution should yield an exponent $\alpha=2$. However, the distribution may be subject to disturbances, perhaps caused by growth processes as suggested above, which temporarily create different slopes of the power law (i.e.,

18 This is in line with the assessment of the changes in the productivity distribution as given by Yu et al. (2015). 
different exponents) before reverting to the Gibrat exponent. Regions currently or recently in transition may experience stronger disturbances and perhaps also disturbances that systematically work into the same direction. (This would also offer an explanation why all deviations from the Gibrat exponent observed for China were upward while the literature provides numerous examples of deviations in both directions for other countries.)

Fourth, regions that experience higher growth may result in systematically different exponents as a result of more rapid technological progress, or of different distributions of productivity, firm age, or product diversity (following the models by Zhang et al. (2009), Helpman et al. (2004), Coad (2010), and Buldyrev et al. (2007) respectively).

Fifth, following preferential attachment models of firm size development (Dahui et al. 2006; Stephen and Toubia 2009), the reforms may have led to the establishment of new connections, especially by and between smaller firms.

Sixth, the large shifts in the ownership structure associated with market reforms may have had an impact on the size distribution, especially since it is reported (though for more recent years) that dynamic characteristics of Chinese firms are strongly dependent on the ownership structure (Duschl and Peng 2015).

Finally, firm ages, which were shown to be inversely related to higher power-law exponents (steeper firm size distributions). They may have a direct effect (as in Coad 2010) or may themselves be a result of a quantity that influences the firm ages, such as bankruptcy (which would also be in line with large number of township and village enterprises but also of state-owned enterprises that were disestablished in connection with the market reforms). A model of a firmage mediated effect on the firm size distribution resulting in both a power law and a specific variation of the exponents between the regions as observed empirically could employ the Yule process. An instance of preferential attachment, the Yule process is known to yield power-law distributions with exponent $\alpha=2$ (Newman 2005). The Yule process starts with a single node and proceeds to add 'children nodes' to randomly (with equal probabilities) selected nodes. The distribution of the number of children follows a power law with $\alpha=2$. It can be modeled as a Markov chain with steady-state conditions (following Newman (2005), with $p(b)$ being the frequency of nodes with $b$ children, $n$ the total number of nodes)

$$
\begin{aligned}
& (n+1) p(1)=n p(1)-p(1)+1 \\
& (n+1) p(b)=n p(b)-b p(b)+(b-1) p(b-1) .
\end{aligned}
$$

It follows $p(1)=1 / 2$ and (where $\sim$ gives the approximation for the tail, i.e. for large $b$ )

$$
\begin{aligned}
& p(b)=\frac{b-1}{b+1} p(b-1)=\frac{2(b-1) !}{(b+1) !} p(1) \\
& =\frac{2(b-1) !}{(b-1) ! b(b+1)} p(1)=\frac{2}{b^{2}+b} p(1)=\frac{2}{b^{2}+b} \sim b^{-2} .
\end{aligned}
$$

Consider a (very simple, stylized) model of increasing returns: Every firm establishes its own technology. Other, smaller, firms can adopt this technology which causes the firm to grow. The smaller firms, in turn, will interconnect their technology and the 'parent technology', which means all adopters of their technology will also adopt the 'parent technology' causing the 'parent firm' to grow further. This is an instance of the Yule process and would therefore create a power law with $\alpha=2$.

To introduce variations in the exponent, consider random bankruptcy of firms. Assume firms that will bankrupt are chosen at random with an average value of $z$ for each firm added to the system by the above Yule process. Further assume, these firms are immediately replaced by a firm of size $1 .{ }^{19}$

19 This ensures that the dynamic is not changed at the level of the total population and that $p(b)$ does not depend on $p(b+1)$. 
Consequently, the above Markov chain becomes

$$
\begin{aligned}
& \qquad(n+1) p(1)=n p(1)-p(1)+1+(1-z) p(1) \\
& (n+1) p(b)=n p(b)-b p(b)+(b-1) p(b-1)-z p(1) \\
& \text { which yields } p(1)=1 /(1+z) \text { and }
\end{aligned}
$$

$$
p(b)=\frac{\Gamma(b) \Gamma(3+z)}{\Gamma(b+2+z)} \frac{1}{1+z}
$$

which can, as shown in Appendix B, be developed into

$$
p(b)=C b^{-2-z} \text {. }
$$

That is, a bankruptcy rate $z$ (at least for $z<1$ ) will increase the exponent of the resulting power law by order $z$ which can be generalized as the relation of death rate and birth rate. Note, however, that for real firm populations it is likely that birth and death rate are correlated, both increasing as the industry becomes more dynamic while rather static firm populations will have low birth and low death rates. The relation of the two influences the (median) firm age which could thus be used as a proxy. Figure 16 and the correlation of median firm ages with the exponents as cited above underlines this possible explanation.

\section{CONCLUSION}

In the present study, we estimated the power-law distribution for firm size measured in terms of 1) the number of employees, 2) capital, 3) gross profit for the provinces of China for the years 1998 through 2008. The case of mainland China is unique for its stepwise transition to market economy in the 1980s and 1990s; this makes it an example that is worth studying not just in order to understand the firm size distribution in China or to prove yet again that firm sizes are indeed power-law distributed, but also in order to investigate the effects behind the emergence of this distribution in virtually every case that was studied. Many scholars (Bak et al. 1988; Mandelbrot and Hudson 2004) have hypothesized that scale-free distribution in itself represents some kind of self-organization; that it indicates a process driven to converge against a distribution by a critical transition or otherwise; a process that likely results from evolutionary mechanisms in the underlying system.

In general agreement with the literature, we found exponents (validated with the KS test and Vuong's test) concentrated between 2.0 and 2.5 (with some few outliers) for the firm size distribution measured in terms of capital and gross profits and slightly higher for the firms size measured in the number of employees. As expo- nents reported in the literature range from 1.4 to 3.7, it would appear that the less steep part, the lower range of exponents (which ever of the expoanations put forward in Section 5 holds) is missing in China.

Comparing the estimated exponents for different regions, a very clear geographical picture emerges. For the Eastern coastal regions, the estimated exponents tend to be higher with moderate levels in the Central part and rather low levels in the Western regions of the country. The same pattern can be recovered from the pattern of GDP growth across the provinces (with the exception of very high growth Inner Mongolia which is, however, mainly resource-based). The pattern of median firm ages in 2008 on the other hand allows a very clear illustration of the regional stages of China's economic reforms: Eastern coastal regions (moderate to high firm ages) first, Central provinces (very low firm ages) second (then recent), Western regions afterwards. Higher power-law exponents indicate smaller dispersion and a lower distribution mass on extreme tail observations; finding the highest exponents in precisely the economic centers of the country where the largest firms concentrate is therefore not an immediately intuitive but still very significant result. It hints at other effects that balance this and at the 
role of a mechanism that appears to stabilize the distribution in spite of changing determinants.

Potential explanations put forward in the section 5 in turn connect the observed patterns to more rapid growth of smaller and medium sized firms as a result of the reforms on the one hand and to bankruptcy patterns on the other hand. The two approaches are not necessarily mutually exclusive; other explanations, involving changes in the ownership structure (away from absolute dominance of state-owned firms), product diversity, or firm age distribution, are conceivable as well.

Of course, any or all of these possible explanations may be connected to the patterns observed in Section 4. Independent from the explanation, however, some stylized facts could be established: the firm size distribution in China likely follows a power law with slightly higher exponents than reported for other countries. This continues to hold in the regional firm size distributions where the parameters differ systematically and appear to be connected to growth and firm age.

\section{Acknowledgements}

For many valuable suggestions we are indebted to two anonymous reviewers, to our colleagues at the IINO in Bremen and the IN-EAST in Duisburg, and to the participants at the ECCS 2014. All remaining errors are our own.

\section{REFERENCES}

Arthur, W. B. (1996): Increasing returns and the new world of business. Harvard Business Review, 74(4): 100-109.

Axtell, R. L. (2001): Zipf distribution of U.S. firm sizes. In: Science 293(5536): 1818-1820. http://www.sciencemag.org/content/293/5536/1818.abstract.

Bak, P. / Tang, C. / Wiesenfeld, K. (1988): Self-organized criticality. In: Physical Review A, 38(1): 364-374.

Battiston, S. / Gatti, D.D. / Gallegati, M. / Greenwald, B. / Stiglitz, J.E. (2007): Credit chains and bankruptcy propagation in production networks. In: Journal of Economic Dynamics and Control, 31(6): 2061-2084 (tenth Workshop on Economic Heterogeneous Interacting Agents WEHIA 2005).

Bottazzi, G. / Cefis, E. / Dosi, G. / Secchi, A. (2007): Invariances and diversities in the patterns of industrial evolution: Some evidence from Italian manufacturing industries. In: Small Business Economics, 29(1-2): 137-159.

Bottazzi, G. / Secchi, A. (2006): Explaining the distribution of firm growth rates. In: The RAND Journal of Economics, 37(2): 235-256.

Buendía, F. (2013): Self-organizing market structures, system dynamics, and urn theory. In: Complexity, 18(4): 28-40.
Buldyrev, S. V. / Growiec, J. / Pammolli, F. / Riccaboni, M. / Stanley, H.E. (2007): The growth of business firms: Facts and theory. In: Journal of the European Economic Association, 5(2-3): 574-584.

Clauset, A. / Shalizi, C. R. / Newman, M. E. J.(2009): Power-law distributions in empirical data. In: SIAM Review, 51: 661-703. http://portal.acm.org/citation. cfm?id=1655787.1655789.

Coad, A. (2010): The exponential age distribution and the pareto firm size distribution. In: Journal of Industry, Competition and Trade, 10(3-4): 389-395.

Dahui, W. / Li, Z. / Zengru, D. (2006): Bipartite producer-consumer networks and the size distribution of firms. In: Physica A: Statistical Mechanics and its Applications, 363(2): 359-366.

Delli Gatti, D. / di Guilmi, C. / Gaffeo, E. / Giulioni, G. / Gallegati, M. / Palestrini, A. (2005): A new approach to business fluctuations: heterogeneous interacting agents, scaling laws and financial fragility. In: Journal of Economic Behavior \& Organization, 56(4): 489-512, Festschrift in honor of Richard H. Day.

Dinlersoz, E. M. / MacDonald, G. (2009): The industry life-cycle of the size distribution of firms. In: Review of Economic Dynamics, 12(4): 648-667. 
Dosi, G. (2007): Statistical regularities in the evolution of industries. A guide through some evidence and challenges for the theory. In: Malerba, F. / Brusoni, S. (Eds.): Perspectives on innovation. Cambridge University Press, Cambridge, UK: 153-186.

Dosi, G. / Marsili, O. / Orsenigo, L. / Salvatore, R. (1995): Learning, market selection and the evolution of industrial structures. In: Small Business Economics, 7(6): 411-436.

Dosi, G. / Pereira, M. C. / Virgillito, M. E., et al. (2015): The foot-print of evolutionary processes of learning and selection upon the statistical properties of industrial dynamics. Tech. rep., Laboratory of Economics and Management (LEM) Working Paper, No. 2015/04, Sant'Anna School of Advanced Studies, Pisa. http:// www.lem.sssup.it/wplem.html.

Duschl, M. / Peng, S.-S. (2015): The patterns of Chinese firm growth: A conditional estimation approach of the asymmetric exponential power density. Industrial and Corporate Change, 24(3): 539-564.

Dutkay, D. E. / Niculescu, C. P. / Popovici, F. (2012): A note on Stirling's formula for the gamma function. In: Journal of Prime Research in Mathematics, 8: 01-04.

Fujimoto, S. / Ishikawa, A. / Mizuno, T. / Watanabe, T. (2011): A new method for measuring tail exponents of firm size distributions. In: Economics: The OpenAccess, Open-Assessment E-Journal, 5: 2011-2020.

Gabaix, X. (1999): Zipf's law for cities: An explanation. In: The Quarterly Journal of Economics, 114(3): 739767.

Gaffeo, E. / Gallegati, M. / Palestrini, A. (2003): On the size distribution of firms: additional evidence from the $\{G 7\}$ countries. In: Physica A: Statistical Mechanics and its Applications, 324(1-2): 117-123, Proceedings of the International Econophysics Conference.

di Giovanni, J. / Levchenko, A. A. / Rancière, R. (2011): Power laws in firm size and openness to trade: Measurement and implications. In: Journal of International Economics, 85(1): 42-52.

Heinrich, T. (2013): Technological change and network effects in growth regimes: Exploring the microfoundations of economic growth. Routledge, Oxon and New York.

Heinrich, T. (2014): Standard wars, tied standards, and network externality induced path dependence in the ICT sector. In: Technological Forecasting and So- cial Change, 81: 309-320. http://www.sciencedirect. com/science/article/pii/S0040162513000917.

Helpman, E. / Melitz, M. / Yeaple, S. (2004): Export versus fdi with heterogeneous firms. In: American Economic Review, 94(1): 300-316.

Ijiri, Y. / Simon, H. A. (1977): Skew distributions and the sizes of business firms. North Holland Publishing, Amsterdam (Studies in Mathematical and Managerial Economics, Vol. 24).

Kwaśnicki, W. (1998): Skewed distributions of firm sizes - an evolutionary perspective. In: Structural Change and Economic Dynamics, 9(1): 135-158.

Luttmer, E.G. J. (2007): Selection, growth, and the size distribution of firms. In: The Quarterly Journal of Economics, 122(3): 1103-1144.

Mandelbrot, B. B. / Hudson, R. L. (2004): The (mis)behavior of markets. Basic Books, New York.

Marsili, 0. (2005): Technology and the size distribution of firms: Evidence from dutch manufacturing. In: Review of Industrial Organization, 27(4): 303-328.

Maschberger, T. / Kroupa, P. (2009): Estimators for the exponent and upper limit, and goodness-of-fit tests for (truncated) power-law distributions. In: Monthly Notices of the Royal Astronomical Society, 395(2): 931-942.

Nelson, R. R. / Winter, S. G. (1982): An Evolutionary Theory of Economic Change. Harvard University Press, Cambridge, MA.

Newman, M.E. J. (2005): Power laws, Pareto distributions and Zipf's law. In: Contemporary Physics, 46(5): 323-351.

Okuyama, K. / Takayasu, M. / Takayasu, H. (1999): Zipf's law in income distribution of companies. In: Physica A: Statistical Mechanics and its Applications, 269(1): 125-131.

Schwardt, H. / Schwesinger, G. (2013): Why are there so many trees in the forest? An analysis of general mechanisms for coexistence in competitive markets. Conference Paper, 16th Conference of the Association for Heterodox Economics, 2014. http://www.hetecon. net/documents/ConferencePapers/2013Non-Refereed/Schwardt Schwesinger AHE2013.pdf (accessed 10.4.2014).

Silverberg, G. / Verspagen, B. (2007): The size distribution of innovations re-visited: An application of extreme value statistics to citation and value measures 
of patent significance. In: Journal of Econometrics, 139(2): 318-339 (The Econometrics of Intellectual Property).

Stephen, A. T. / Toubia, 0. (2009): Explaining the power-law degree distribution in a social commerce network. In: Social Networks, 31(4): 262-270.

Sun, C. / Zhang, T. (2012): Export, productivity pattern, and firm size distribution (36742). http://mpra.ub. uni-muenchen.de/36742/.
Yu, X. / Dosi, G. / Lei, J. / Nuvolari, A. (2015): Institutional change and productivity growth in China's manufacturing: The microeconomics of knowledge accumulation and "creative restructuring". In: Industrial and Corporate Change, 24(3): 565-602.

Zhang, J. / Chen, Q. / Wang, Y. (2009): Zipf distribution in top Chinese firms and an economic explanation. In: Physica A: Statistical Mechanics and its Applications, 388(10): 2020-2024.

\section{APPENDIX}

\section{A DERIVATION OF THE TRANSFORMATION $y=k \sqrt[h]{x}$ ON THE POWER-LAW DISTRIBUTION}

PDFs resulting from continuous invertible transformations $y=g(x)$ on continuous random variables $x$ are given as

$$
p(y)=\frac{d g^{-1}}{d y} p\left(g^{-1}\right) .
$$

Hence, the transformation $y=g(x)=k \sqrt[h]{x}=k x^{1 / h}$ (with $h>1$ and $k>>0$ ) on $p(x)=C x^{-\alpha}$ yields

$$
\begin{aligned}
& g^{-1}(y)=\left(\frac{y}{k}\right)^{h} \\
& \frac{d g^{-1}}{d y}=h k^{-h} y^{h-1} \\
& p(y)=\frac{d g^{-1}}{d y} p\left(g^{-1}\right)=h k^{-h} y^{h-1} C k^{\alpha h} y^{-\alpha h}=C h k^{h(1-\alpha)} y^{-\alpha h-1+h}=\tilde{C} y^{-\alpha h-1+h}
\end{aligned}
$$

where $\tilde{C}=C_{h} k^{h(1-\alpha)}$ is the new constant and the new exponent is larger than the old one (if $\alpha>1$ ) since

$$
\begin{aligned}
& \alpha h+1-h>\alpha \\
& \alpha h-\alpha=\alpha(h-1)>h-1 \\
& \alpha>1 .
\end{aligned}
$$




\section{B APPROXIMATION OF THE DISTRIBUTION $p(b, z)$ OF THE MODIFIED YULE PROCESS}

The Markov chain

$$
\begin{aligned}
& (n+1) p(1)=n p(1)-p(1)+1+(1-z) p(1) \\
& (n+1) p(b)=n p(b)-b p(b)+(b-1) p(b-1)-z p(1)
\end{aligned}
$$

yields $p(1)=1 /(1+z)$ and

$$
p(b)=\frac{b-1}{b+1+z} p(b-1)=\frac{\Gamma(b-1+1) \Gamma(2+z+1)}{\Gamma(b+1+z+1)} p(1)=\frac{\Gamma(b) \Gamma(3+z)}{\Gamma(b+2+z)} p(1)=\frac{\Gamma(b) \Gamma(3+z)}{\Gamma(b+2+z)} \frac{1}{1+z} .
$$

Note that we have to use the Gamma function (which is the continuous extension of the factorial with $n !=\Gamma(n+1))$ since the factorial is not defined over non-integer values. The Markov chain is unfortunately not as conveniently solved as the one above. However, using Stirling's approximation (Dutkay et al. 2012)

$$
m !=\Gamma(m+1) \approx \sqrt{2 \pi} m^{m+0.5} e^{-m}=\sqrt{2 \pi m}\left(\frac{m}{e}\right)^{m}
$$

we obtain ( again giving the approximation of the tail, i.e. for large $b$ )

$$
\begin{aligned}
& p(b) \approx \frac{\sqrt{2 \pi(b-1)}\left(\frac{b-1}{e}\right)^{b-1} \sqrt{2 \pi(2+z)}\left(\frac{2+z}{e}\right)^{2+z}}{\sqrt{2 \pi(b+1+z)}\left(\frac{b+1+z}{e}\right)^{b+1+z}} \frac{1}{1+z} \\
& p(b)=\sqrt{2 \pi \frac{(b+1)(2+z)}{b+1+z}\left(\frac{2+z}{e}\right)^{2+z} e^{-2-z} \frac{1}{1+z} \frac{(b-1)^{b-1}}{(b+1+z)^{b+1+z}}} \\
& p(b)=C \frac{(b-1)^{b-1}}{(b+1+z)^{b+1+z}} \sim C b^{(b-1)-(b+1+z)}=C b^{-2-z} .
\end{aligned}
$$

That is, a bankruptcy rate $z$ (at least for $z<1$ ) will increase the exponent of the resulting power law by order $z$. To illustrate this, a simulation of this system for different $z$ is added in Figure 17. Note that $z$ may be seen as a death rate in the resulting process that is contrasted to a birth rate 1 (the velocity of the Yule process itself, the speed at which new nodes are added, 1 per iteration). The resulting property can thus be generalized as death rate $/$ birth rate $=z / 1=z$.

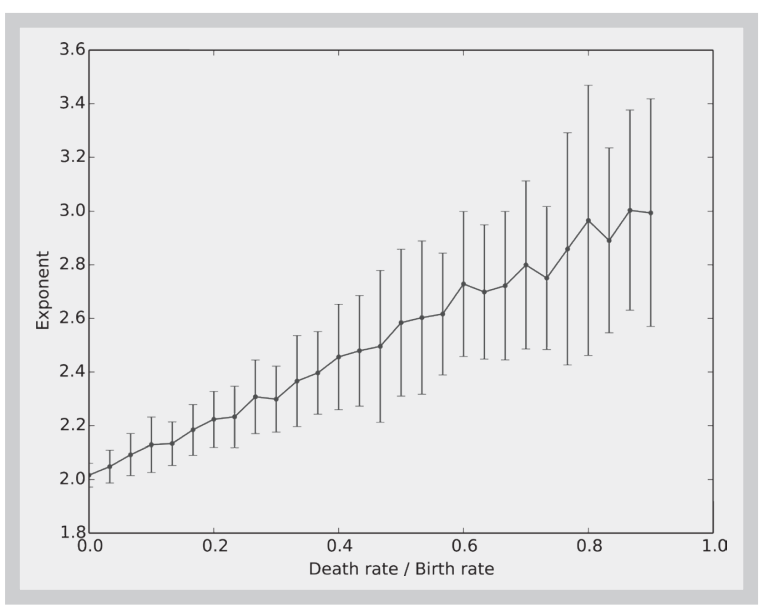




\section{WORKING PAPERS ON EAST ASIAN STUDIES BACK ISSUES}

No. 106 / 2015 Ralf Bebenroth, Kai Oliver Thiele: Identification to Oneself and to the Others: Employees' Perceptions after a Merger

No. 105 / 2015 Jun Gu, Annika Mueller, Ingrid Nielsen, Jason Shachat, Russell Smyth: Reducing Prejudice through Actual and Imagined Contact: A Field Experiment with Malawian Shopkeepers and Chinese Immigrants

No. 104 / 2015 Marcus Conlé: Architectural Innovation in China. The Concept and its Implications for Institutional Analysis

No. 103 / 2015 Kai Duttle, Tatsuhiro Shichijo: Default or Reactance? Identity Priming Effects on Overconfidence in Germany and Japan

No. 102 / 2015 Martin Hemmert: The Relevance of Interpersonal and Inter-organizational Ties for Interaction Quality and Outcomes of Research Collaborations in South Korea

No. 101 / 2015 Shuanping Dai, Wolfram Elsner: Declining Trust in Growing China. A Dilemma between Growth and Socio-Economic Damage

No. 99 / 2014 Anna L. Ahlers, Thomas Heberer, Gunter Schubert: 'Authoritarian Resilience' and Effective Policy Implementation in Contemporary China - A Local State Perspective

No. 98 / 2014 Werner Pascha: The Potential of Deeper Economic Integration between the Republic of Korea and the EU, Exemplified with Respect to E-Mobility

No. 97 / 2014 Anja Senz, Dieter Reinhardt (Eds.): Task Force: Connecting India, China and Southeast Asia - New Socio-Economic Developments

No. 96 / 2014 Markus Taube: Grundzüge der wirtschaftlichen Entwicklung und ihre ordnungspolitischen Leitbilder in der VR China seit 1949

No. 95 / 2013 Yasuo Saeki, Sven Horak: The Role of Trust in Cultivating Relation-specific Skills - The Case of a Multinational Automotive Supplier in Japan and Germany

No. 94 / 2013 Heather Xiaoquan Zhang, Nicholas Loubere: Rural Finance, Development and Livelihoods in China

No. 93 / 2013 Thomas Heberer, Anja Senz (Hg.): Task Force: Wie lässt sich die Zusammenarbeit des Landes Nordrhein-Westfalen mit China und den NRW-Partnerprovinzen vertiefen?

No. 92 / 2013 Sven Horak: Cross-Cultural Experimental Economics and Indigenous Management Research - Issues and Contributions

No. 91 / 2013 Jann Christoph von der Pütten, Christian Göbel (Hg.): Task Force: Gewerkschaften, Arbeitsmarktregulierung und Migration in China

No. 90 / 2012 Thomas Heberer: Some Reflections on the Current Situation in China
No. 89 / 2011 Susanne Löhr, René Trappel (Hg.): Task Force: Nahrungsmittel in China - Food-Security- und FoodSafety-Problematik in China

No. 88 / 2011 Peter Thomas in der Heiden: Chinese Sectoral Industrial Policy Shaping International Trade and Investment Patterns - Evidence from the Iron and Steel Industry

No. 87 / 2010 Marcus Conlé: Health Biotechnology in China: National, Regional, and Sectoral Dimensions

No. 86 / 2010 Anja Senz, Dieter Reinhardt (eds.): Green Governance - One Solution for Two Problems? Climate Change and Economic Shocks: Risk Perceptions and Coping Strategies in China, India and Bangladesh

No. 85 / 2010 Heather Xiaoquan Zhang: Migration, Risk and Livelihoods: A Chinese Case

No. 84 / 2010 Marcus Conlé, Markus Taube: Anatomy of Cluster Development in China: The case of health biotech clusters

No. 83 / 2010 Sven Horak: Aspects of Inner-Korean Relations Examined from a German Viewpoint

No. 82 / 2010 Thomas Heberer, Anja-D. Senz (Hg.): Chinas Rolle in den internationalen Beziehungen - globale Herausforderungen und die chinesische Außenpolitik

No. 81 / 2009 Flemming Christiansen, Heather Xiaoquan Zhang: The Political Economy of Rural Development in China: Reflections on Current Rural Policy

No. 80 / 2009 Chan-Mi Strüber: Germany's Role in the Foreign Direct Investment Configuration of Korean Multinational Enterprises in Europe

No. 79 / 2009 Thomas Heberer, Anja-D. Senz (Hg.): Task Force: Entwicklungspolitik und -strategien in Ostasien am Beispiel der chinesischen Umweltpolitik

No. 78 / 2008 Werner Pascha, Cornelia Storz: How are Markets Created? The Case of Japan's Silver Market

No. 77 / 2008 Werner Pascha, Uwe Holtschneider (Hg.): Task Force: Corporate Social Responsibility in Japan und Österreich

No. 76 / 2008 Yu Keping: China's Governance Reform from 1978 to 2008

No. 75 / 2008 Thomas Heberer: Task Force: Entwicklungspolitik in China: Herausforderungen, Lösungsstrategien und deutsch-chinesische Entwicklungszusammenarbeit

No. 74 / 2008 Markus Taube: Ökonomische Entwicklung in der VR China. Nachholendes Wachstum im Zeichen der Globalisierung

No. 73 / 2007 Norifumi Kawai, Manja Jonas: Ownership Strategies in Post-Financial Crisis South-East Asia: The Case of Japanese Firms 
No. 72 / 2007 Werner Pascha, Cornelia Storz, Markus Taube (Eds.): Workshop Series on the Role of Institutions in East Asian Development - Institutional Foundations of Innovation and Competitiveness in East Asia

No. 71 / 2006 Norifumi Kawai: Spatial Determinants of Japanese Manufacturing Firms in the Czech Republic

No. 70 / 2006 Werner Pascha, Cornelia Storz (Hg.): Workshop Institutionen in der Entwicklung Ostasiens I - Offenheit und Geschlossenheit asiatischer Wirtschaftssysteme

No. 69 / 2006 Christian Göbel: The Peasant's Rescue from the Cadre? An Institutional Analysis of China's Rural Tax and Fee Reform

No. 68 / 2006 Thomas Heberer: Institutional Change and Legitimacy via Urban Elections? People's Awareness of Elections and Participation in Urban Neighbourhoods (Shequ)

No. 67 / 2006 Momoyo Hüstebeck: Tanaka Makiko: Scharfzüngige Populistin oder populäre Reformerin?

No. 66 / 2006 Momoyo Hüstebeck: Park Geun-hye: Als Präsidententochter zur ersten Staatspräsidentin Südkoreas?

No. 65 / 2006 Werner Pascha, Cornelia Storz (Hg.): Workshop Organisation und Ordnung der japanischen Wirtschaft V. Themenschwerpunkt: Deutschlandjahr in Japan - eine Zwischenbilanz

No. 64 / 2004 Christian Göbel, Thomas Heberer (Hg.): Task Force: Zivilgesellschaftliche Entwicklungen in China / Task Force: Civil Societal Developments in China

No. 63 / 2005 Thorsten Nilges: Zunehmende Verschuldung durch Mikrokredite. Auswertung eines Experiments in Südindien

No. 62 / 2004 Jun Imai: The Rise of Temporary Employment in Japan. Legalisation and Expansion of a Non-Regular Employment Form

No. 61 / 2004 Thomas Heberer, Nora Sausmikat: Bilden sich in China Strukturen einer Zivilgesellschaft heraus?

No. 60 / 2004 Thomas Heberer, Anja Senz (Hg.): Feldforschung in Asien: Erlebnisse und Ergebnisse aus der Sicht politikwissenschaftlicher Ostasienforschung

No. 59 / 2004 Li Fan: Come by the Wind. Li Fan's Story in Buyun Election

No. 58 / 2004 Li Minghuan: Labour Brokerage in China Today: Formal and Informal Dimensions

No. 57 / 2004 Dorit Lehrack: NGO im heutigen China Aufgaben, Rolle und Selbstverständnis

No. 56 / 2004 Anja Senz: Wählen zwischen Recht und Pflicht - Ergebnisse einer Exkursion der Ostasienwissenschaften in die Provinz Sichuan / VR China

No. 55 / 2004 Werner Pascha, Cornelia Storz: Workshop Organisation und Ordnung der japanischen Wirtschaft IV. Themenschwerpunkt: Wahrnehmung, Institutionenökonomik und Japanstudien
No. 54 / 2004 Thomas Heberer: Ethnic Entrepreneurs as Agents of Social Change. Entrepreneurs, clans, social obligations and ethnic resources: the case of the Liangshan $\mathrm{Yi}$ in Sichuan

No. 53 / 2003 Hermann Halbeisen: Taiwan's Domestic Politics since the Presidential Elections 2000

No. 52 / 2003 Claudia Derichs, Wolfram Schaffar (Hg.): Task Force: Interessen, Machstrukturen und internationale Regime. Die WTO-Verhandlungen zum GATS (Dienstleistungsabkommen) und sein Einfluss auf Asien

No. 51 / 2003 Markus Taube: Chinas Rückkehr in die Weltgemeinschaft. Triebkräfte und Widerstände auf dem Weg zu einem "Global Player"

No. 50 / 2003 Kotaro Oshige: Arbeitsmarktstruktur und industrielle Beziehungen in Japan. Eine Bestandsaufnahme mit Thesen zur Zukunftsentwicklung

No. 49 / 2003 Werner Pascha, Cornelia Storz (Hg.): Workshop Organisation und Ordnung der japanischen Wirtschaft III. Themenschwerpunkt: Institutionenökonomik und Japanstudien

No. 48 / 2003 Institute of East Asian Studies (Ed.), Frank Robaschik (compilation), with contributions from Winfried Flüchter, Thomas Heberer, Werner Pascha, Frank Robaschik, Markus Taube: Overview of East Asian Studies in Central and Eastern Europe

No. 47 / 2002 Ulrich Zur-Lienen: Singapurs Strategie zur Integration seiner multi-ethnischen Bevölkerung: Was sich begegnet gleicht sich an

No. 46 / 2002 Thomas Heberer: Strategische Gruppen und Staatskapazität: Das Beispiel der Privatunternehmer in China

No. 45 / 2002 Thomas Heberer, Markus Taube: China, the European Union and the United States of America: Partners or Competitors?

No. 44 / 2002 Werner Pascha: Wirtschaftspolitische Reformen in Japan - Kultur als Hemmschuh?

No. 43 / 2002 Werner Pascha, Klaus Ruth, Cornelia Storz (Hg.): Themenschwerpunkt: Einfluss von IT-Technologien auf Strukturen und Prozesse in Unternehmen

No. 42 / 2002 Karin Adelsberger, Claudia Derichs, Thomas Heberer, Patrick Raszelenberg: Der 11. September und die Folgen in Asien. Politische Reaktionen in der VR China, Japan, Malaysia und Vietnam

No. 41 / 2001 Claudia Derichs, Thomas Heberer (Hg.): Task Force: Ein Gutachten zu Beschäftigungspolitik, Altersvorsorge und Sozialstandards in Ostasien

No. 40 / 2001 Werner Pascha, Frank Robaschik: The Role of Japanese Local Governments in Stabilisation Policy

No. 39 / 2001 Anja Senz, Zhu Yi: Von Ashima zu Yi-Rap: Die Darstellung nationaler Minderheiten in den chinesischen Medien am Beispiel der Yi-Nationalität

No. 38 / 2001 Claudia Derichs: Interneteinsatz in den Duisburger Ostasienwissenschaften: Ein Erfahrungsbericht am Beispiel des deutsch-japanischen Seminars „DJ50“ 
No. 37 / 2001 Zhang Luocheng: The particularities and major problems of minority regions in the middle and western parts of China and their developmental strategy

No. 36 / 2001 Thomas Heberer: Falungong - Religion, Sekte oder Kult? Eine Heilsgemeinschaft als Manifestation von Modernisierungsproblemen und sozialen Entfremdungsprozessen

No. 35 / 2001 Claudia Derichs, Thomas Heberer, Patrick Raszelenberg (Hg.): Task Force: Ein Gutachten zu den politischen und wirtschaftlichen Beziehungen Ostasien-NRW

No. 34 / 2000 Ulrich Jürgens, Werner Pascha, Cornelia Storz (Hg.): Workshop Organisation und Ordnung der japanischen Wirtschaft I. Themenschwerpunkt: "New Economy“ - Neue Formen der Arbeitsorganisation in Japan

No. 33 / 2000 Winfried Flüchter: German Geographical Research on Japan

No. 32 / 2000 Thomas Heberer, Sabine Jakobi: Henan The Model: From Hegemonism to Fragmentism. Portrait of the Political Culture of China's Most Populated Province

No. 31 / 2000 Thomas Heberer: Some Considerations on China's Minorities in the 21st Century: Conflict or Conciliation?

No. 30 / 2000 Jun Imai, Karen Shire: Flexible Equality: Men and Women in Employment in Japan

No. 29 / 2000 Karl Lichtblau, Werner Pascha, Cornelia Storz (Hg.): Workshop Klein- und Mittelunternehmen in Japan V. Themenschwerpunkt: M \& A in Japan - ein neues Instrument der Unternehmenspolitik?

No. 28 / 1999 Rainer Dormels: Regionaler Antagonismus in Südkorea

No. 27 / 1999 Claudia Derichs, Tim Goydke, Werner Pascha (Hg.): Task Force: Ein Gutachten zu den deutschen/europäischen Außen- und Außenwirtschaftsbeziehungen mit Japan

No. 26 / 1999 Susanne Steffen: Der Einsatz der Umweltpolitik in der japanischen Elektrizitätswirtschaft

No. 25 / 1999 Claudia Derichs: Nationbuilding in Malaysia under Conditions of Globalization

No. 24 / 1999 Thomas Heberer, Arno Kohl, Tuong Lai, Nguyen Duc Vinh: Aspects of Privat Sector Development in Vietnam

No. 23 / 1999 Werner Pascha: Corruption in Japan An Economist's Perspective

No. 22 / 1999 Nicole Bastian: Wettbewerb im japanischen Fernsehmarkt. Neue Strukturen durch Kabel- und Satellitenfernsehen? Eine wettbewerbstheoretische Analyse

No. 21 / 1999 Thomas Heberer: Entrepreneurs as Social Actors: Privatization and Social Change in China and Vietnam

No. 20/1999 Vereinigung für sozialwissenschaftliche Japan-Forschung (Hg.): Quo vadis sozialwissenschaftliche Japan-Forschung? Methoden und Zukunftsfragen

No. 19 / 1999 Bong-Ki Kim: Das Problem der interkulturellen Kommunikation am Beispiel der Rezeption Deweys in China
No. 18 / 1998 Werner Pascha, Cornelia Storz (Hg.): Workshop Klein- und Mittelunternehmen in Japan IV. Themenschwerpunkt Netzwerke

No. 17 / 1998 Andreas Bollmann, Claudia Derichs, Daniel Konow, Ulrike Rebele, Christian Schulz, Kerstin Seemann, Stefanie Teggemann, Stephan Wieland: Interkulturelle Kompetenz als Lernziel

No. 16 / 1997 Werner Pascha, Cornelia Storz (Hg.): Workshop Klein- und Mittelunternehmen in Japan III. Themenschwerpunkt Innovation

No. 15 / 1997 Winfried Flüchter: Tokyo quo vadis? Chancen und Grenzen (?) metropolitanen Wachstums

No. 14 / 1997 Claudia Derichs: Der westliche Universalitätsanspruch aus nicht-westlicher Perspektive

No. 13 / 1997 Werner Pascha: Economic Globalization and Social Stabilization: A Dual Challenge for Korea

No. 12 / 1996 Claudia Derichs: Kleine Einführung in die Politik und das politische System Japans

No. 11 / 1996 Mikiko Eswein: Die Rolle der Berufsbildung beim sozialen Wandel in Japan

No. 10 / 1996 Mikiko Eswein: Erziehung zwischen Konfuzianismus und Bismarck. Schule und Erziehungssystem in Japan

No. 9 / 1996 Werner Pascha: On the Relevance of the German Concept of "Social Market Economy" for Korea

No. 8 / 1996 Carsten Herrmann-Pillath: Strange Notes on Modern Statistics and Traditional Popular Religion in China: Further Reflections on the Importance of Sinology for Social Science as applied on China

No. 7 / 1996 Ralph Lützeler: Die japanische Familie der Gegenwart - Wandel und Beharrung aus demographischer Sicht

No. 6 / 1995 Werner Pascha (Hg.): Klein- und Mittelunternehmen in Japan - Dokumentation eines Workshops

No. 5 / 1995 Chen Lai: Die Kultur des Volkskonfuzianismus: Eine Untersuchung der Literatur zur kindlichen Erziehung (Meng xue)

No. 4 / 1995 Carsten Herrmann-Pillath: Die Volksrepublik und die Republik China: Die Gratwanderung zweier chinesischer Staaten zwischen Politik und Wirtschaft

No. 3 / 1995 Carsten Herrmann-Pillath: On the Importance of Studying Late Qing Economic and Social History for the Analysis of Contemporary China or: Protecting Sinology Against Social Science

No. 2 / 1995 H. J. Beckmann, K. Haaf, H. Kranz, W. Pascha, B. Slominski, T. Yamada: „Japan im Netz“. Eine Materialsammlung zur Nutzung des Internet

No. 1 / 1995 Claudia Derichs, Winfried Flüchter, Carsten Herrmann-Pillath, Regine Mathias, Werner Pascha: Ostasiatische Regionalstudien: Warum? 